\title{
Local Rule of Đại Việt under the Lý Dynasty: Evolution of a Charter Polity after the Tang-Song Transition in East Asia
}

\author{
MOMOKI Shiro \\ Osaka University \\ Osaka, Japan \\ momoki@cscd.osaka-u.ac.jp
}

\begin{abstract}
Empirical research into Đại Việt before the $14^{\text {th }}$ century has made little progress since the 1990s. To improve this situation, I here examine how the Lý dynasty (1009-1226), the first long-lasting dynasty of Đại Việt, established stable local ruleafter the "Tang-Song Transition" in China that changed the entire picture of East Asia (including both Southeast and Northeast Asia). This paper focuses on two issues. First are the local administrative units and their governors. The nature of both higher units like lọ (circuits), phu and châu (provinces), and basic units like hưong and giáp (districts?) will be examined. Second, I examine non-institutional channels of local rule by the imperial family. By combining such administrative and non-administrative means, the Lý central court enforced a considerably stable local rule for two centuries. Finally, I attempt some preliminary comparisons with the local rule of Goryeo (918-1392) in the Korean peninsula, a polity that shared many features with Đai Viẹt in the process of localization of the Tang and Song models. I hope this approach of viewing small empires from the standpoint not of their "goal" (modern states) but of their "start" (charter polities), will enrich the discussion of East Asian small empires.
\end{abstract}




\section{Keywords}

Đại Việt, the Lý Dynasty, Local rule, Tang-Song Transition, Goryeo

\section{A SOlar Polity OR A CENTRALIZED STATE?}

During the 1970s and the 1980s, the conventional "Sinicised" image of Đại Việt (Vietnam) as a strongly centralized bureaucratic state was replaced, especially for its early phase before the $14^{\text {th }}$ century, with a more "Southeast Asian" image of a polity with physically loose administrative institutions and bold ideological claims of the ruler's universal authority. Even in Vietnam, the Marxist model of "Asiatic Mode of Production" was appropriated for the phase before the $14^{\text {th }}$ century in order to explain the simplicity of administrative apparatus and the closeness between the ruler and the ruled (compared to the "centralized feudal system" with "despotic" rule after the $15^{\text {th }}$ century). ${ }^{2}$ In his recent global

${ }^{1}$ See, for example, Oliver W. Wolters, "Le Van Huu's Treatment of Ly Than Ton's Reign," in Southeast Asian History and Historiography, ed. C. D. Cowan and Oliver Wolters (Ithaca: Cornell University Press, 1976), 1127-1137, and Keith W. Taylor, "Authority and Legitimacy in $11^{\text {th }}$ Century Vietnam," in Southeast Asia in the $9^{\text {th }}$ to $14^{\text {th }}$ Centuries, ed. David Marr and A. C. Milner (Singapore: Institute of Southeast Asian Studies, 1986). They worked on such topics as political authority and legitimacy, and their articulation in historiography and literature. Sakurai Yumio ("Richo-ki [1010-1225] Koga deruta kaitaku shiron [The Red River Delta during the Lý Period]," Tonan Ajia Kenkyu 18, no. 2 (1980) (Southeast Asian Studies, Kyoto University) and do, Land, Water, Rice, and Men in Early Vietnam: Agrarian Adaptation and Socio-Political Organization, Keith W. Taylor, ed., Thomas A. Stanley (trans.), n.d.) shed light on the small scale and the diversity of agricultural production that must not have supported a monolithic centralized administration. Despite his initial hesitation in the first edition of his mandala theory (Oliver W. Wolters, History, Culture, and Region in Southeast Asian Perspective [Singapore: Institute of Southeast Asian Studies, 1982]), Wolters finally treated Đại Việt till the $14^{\text {th }}$ century as one of Southeast Asian mandalas (Wolters, History, Culture, and Region in Southeast Asian Perspectives, revised ed. (Singapore: Institute of Southeast Asian Studies, 1999). In Russia, Poliacoff (Poliacốp, A.B. [Vũ Minh Giang và Vũ Văn Quân trans.], Sự phục hưng của nước Đại Việt thế kỷ X-XIV [The Revival of Dai Viet during the $10^{\text {th }}$ to $14^{\text {th }}$ Centuries], Hà Nội: Nhà Xuất bản Chính trị Quốc gia, 1996.) also doubted the centralized and confucianistc rule before the Trần Dynasty (1226-1400).

${ }^{2}$ See Lê Kim Ngân, "Một giả thiết về kết cấu kinh tế của xã hội Việt Nam từ thế kỷ X đến thế kỷ XIV: Nguồn gốc phát sinh và sự tiến triển của nó (A hypothesis concerning the economic formation of Vietnamese society from the $10^{\text {th }}$ to the $14^{\text {th }}$ centuries: Its origine and evolution)," in Viện Sử học (Institute of History), Tìm hiểu xã hội Việt Nam thời Lý-Trần (Research in Vietnamese society during the Lý-Trần period), Hà Nội: Nhà Xuất bản Khoa học Xã hội, 1981, and Tran Quoc Vuong, "Traditions, Acculturation, Renovation: The Evolutional Pattern of Vietnamese Culture," in Southeast Asia in the $9^{\text {th }}$ to $14^{\text {th }}$ Centuries, ed. David Marr and A. C. Milner (1986), for instance. 
comparisons, Lieberman described Đại Việt before its collapse in the $14^{\text {th }}$ century as a "solar polity", in which the central power could enforce strong control only in the core region, and cultural integration in both horizontal and vertical directions was still in an early phase ${ }^{3}$. Nevertheless, orthodox historiography in Vietnam still insists that the Lý Dynasty (1009-1226), the first long-lasting dynasty of Đại Việt after its foundation in the $10^{\text {th }}$ century, had already established a centralized state system, though it had not yet been "despotic" as the phase after the $15^{\text {th }}$ Century ${ }^{4}$. This gap partly reflects the current political framework of Vietnam which eulogizes the "unity in diversity" of the nation. At the same time, however, scholars should pay more attention to methodological problems of earlier debates (both inside and outside Vietnam), including deficiencies in theoretical considerations and textual/empirical examinations concerning the relationship between the dynastic constitution and the daily reality.

Taking such academic circumstances into consideration, I consider here how the central power of the Lý Dynasty enforced a stable local rule during the period of the "Tang-Song Transition"

${ }^{3}$ Victor Lieberman, Strange Parallels: Southeast Asia in Global Context, c.800-1830, volume 1: Integration on the Mainland (New York: Cambridge University Press, 2003) and volume 2: Mainland Mirrors: Europe, Japan, China, South Asia, and the Islands (New York: Cambridge University Press, 2009).

${ }^{4}$ For recent arguments, see Phạm Đức Anh, "Về tính chất tập quyền trong thiết chế chính trị triều Lý (On the Centralized Nature of Power in the Ly's Administraiton [1009-1225]," Nghiên cúu Lịch sư (Historical Studies) 426 (2011) and Trần Thị Vinh, "Thể chế chính trị Việt Nam thế kỷ XI - XIII dưới triều Lý (Vietnamese Political Regime during the $11^{\text {th }}$ to the $13^{\text {th }}$ Centuries under the Ly Dynasty)," in Ủy ban Nhân dân Thành phố Hà Nội (The Peoples Committee of Hanoi city), Kỷ yếu hội thảo khoa học: 1000 năm vurong triều Lý và kinh đô Thăng Long (Proceedings of the Scientific Symposium: 1,000 Years of the Ly Dynasty and the Thang Long Capital), Hà Nội: Nhà Xuất bản Thế giới, 2009. See also general histories (like Viện Sử học, Lịch sủ Việt Nam thế kỷ X-đầu thế lỷ XV [The History of Vietnam from the $10^{\text {th }}$ to the beginning of the $15^{\text {th }}$ Century], Hà Nội: Nhà Xuất bản Khoa học Xã hội,2002) and the general evaluation of the Lý Dynasty in the memorial publications of the $1,000^{\text {th }}$ anniversary of the Thăng Long Capital (as Nguyễn Quang Ngọc ed., Vuoong triều Lý [1009-1226] [The Lý Dynasty (1009-1226)] [Hà Nội: Nhà Xuất bản Hà Nội, 2011]). The paper of Phạm Đức Anh is of special interest because of his criticism of Japanese and American scholars on the one hand, and his inductive examination of local administrative units on the other. 
Map 1. Đại Việt during the Lý Period [adapted from Map 6-1 in Momoki, Chusei Daietsu, 228]

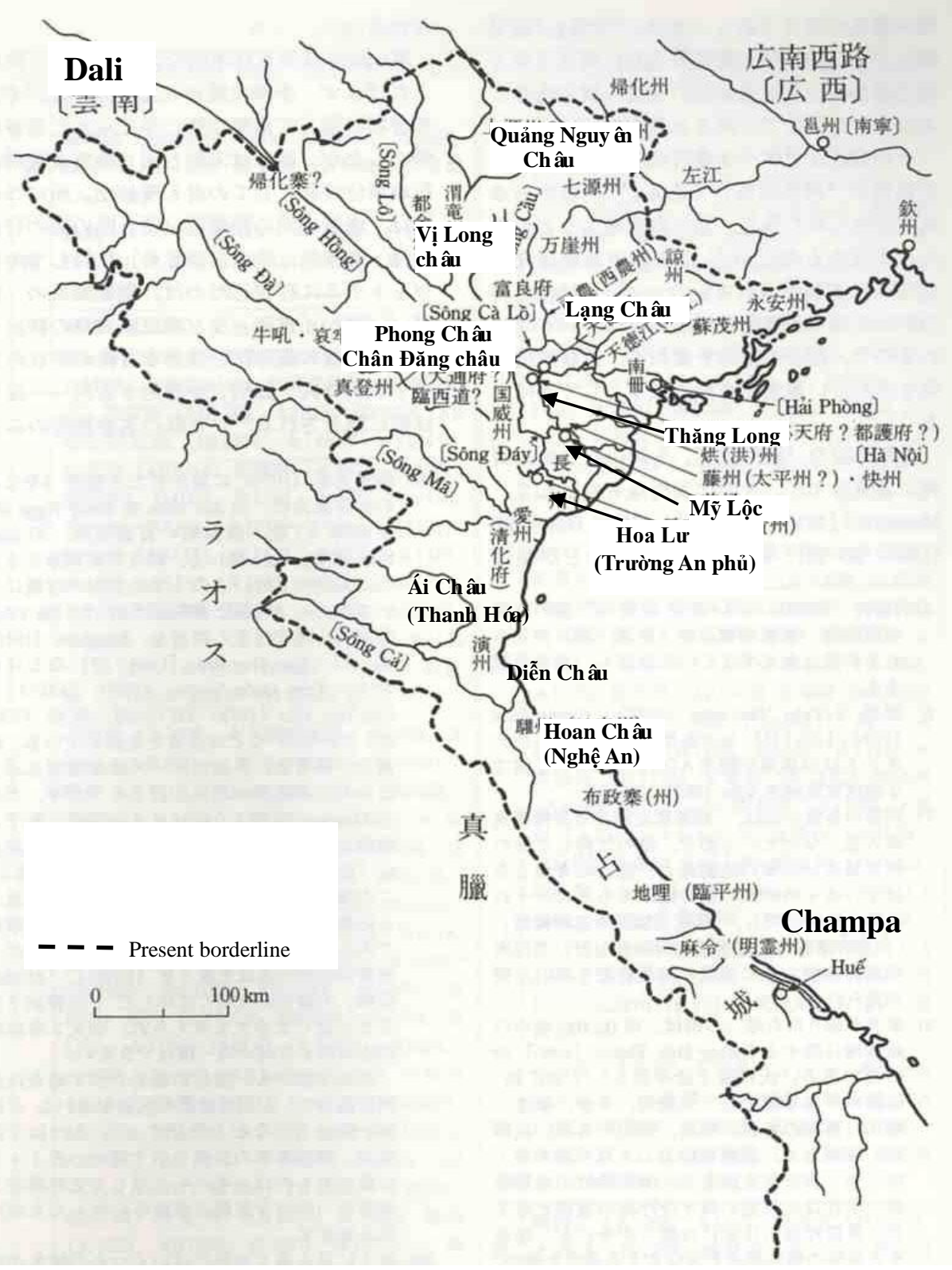

of the Sinic World. My investigation of the local rule of the Lý Dynasty rests mainly on inductive analysis of major sources and partly on inferences drawn from comparison with China and Korea. To attain my goal, I examine two issues. The first is the modification and localization of the Chinese-modeled hierarchy of local administrative units. The second is the non-institutional relationship between the imperial court and local powers. ${ }^{5}$

${ }^{5}$ Such inductive research was conducted first by Sakurai Yumio, "Richo-ki" and then by me ("Vetonamu Richo-no gunji-kodo to chiho-shihai (Military Activities and Local Rule of the Ly Dynasty in Vietnam)," Tonan Ajia Kenkyu (Southeast Asian Studies, Kyoto Universi- 


\title{
II. LOCAL UNITS AND THEIR GOVERNORS
}

\section{Three Interpretations of the Lộ (Circuit) System}

\begin{abstract}
Along with the famous record of the relocation of the capital to Thăng Long in the seventh lunar month of 1010, the dynastic annals Đại Việt sử ký toàn thư (hereafter TT) also include the following well-known record for the end of 1010.
\end{abstract}

Converted ten units of đạo 道 into twenty-four lộ 路 units and [among these lộ units?] made Hoan Châu (present-day Nghệ An and Hà Tĩnh area) and Ái Châu (Thanh Hóa) trại 寨.

Many textbooks and general histories mention this event as evidence of centralized rule, regarding lọ units as local administrative units of the highest rank. However, as Sakurai Yumio pointed out ${ }^{6}$, this record is not entirely reliable ${ }^{7}$, first of all because the event is not recorded in other annals of Đại Việt, namely, Đại Việt sư lược ${ }^{8}$ (hereafter $\mathrm{SL}^{9}$ ). Regarding the lọ (circuit)

ty) 24, no. 4 (1987), and "Vetonamu Richo-no chiho gyosei-tan'i to chiho tochisha (Local Administrative Units and Local Rulers of the Ly Dynasty in Vietnam)," Tonan Ajia Kenkyu 26 , no. 3 (1988), both with insufficient theoretical analysis. Recently I resumed the research and published my findings in chapter 6 of my book (Momoki, Chusei Daietsu) in Japanese with lists of topomyms accompanied by unit names (Ibid, 229-236: Tables 6-1 to 6-4). The most basic list based on the two dynastic annals, namely Đại Việt sủ lược and Đại Việt sứ ký toàn thu (Ibid, 232-4: Table 6-2), was also reproduced in Momoki, "Local Rule of Đại Việt under the Lý dynasty: Evolution of a Charter Polity after the Tang-Song Transition in East Asia," paper presented at the annual congress of AAS, Toronto, March 15-18, 2012. The current paper elaborates the arguments of this AAS paper, also with the table (see the end of the paper).

${ }^{6}$ Sakurai, "Richo-ki," 274.

7 TT itself is contradictory, because an entry for the year 1002 had already recorded that

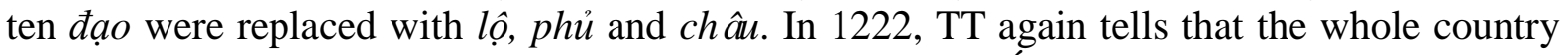
was divided into twenty-four $l \hat{\text {. }}$. Moreover, Hoan Châu and Ái châu are never called trại after 1010. The record that Hoan Châu and Ái châu were made trại may have been invented after the Trần demarcation during 1256-73 (recorded in TT), when Thanh Hóa and Nghệ An were treated as trai in contrast to the kinh 京 region (probably covering the Red River Delta) as the boundary of civil examination. If so, the record of trai in 1010 is of no use for the purpose of investigating the nature of trại units during the Lý period that indeed appear in the annals as shown in the Table in the end of this paper. See also note 40 below.

${ }^{8}$ Cheng Ching-ho (Kogobon Daietsu Shiryaku (A Collated Text of Đại Việt sủ luoơc), 
system in particular and the hierarchy of local administrative units in general, there are actually three different interpretations.

Henri Maspéro asserted that đạo during the Đinh and Lê periods was a unit of military and inspectional affairs as was the case of the Tang, but $l \hat{o}$ was rather analogous to the Tang's military unit of dodufu 都督府 under đạo, and each region had several lọ units which belonged to the lọ of the seat of regional government (phủ lọ 府路). ${ }^{10}$ In Maspéro's opinion ${ }^{11}$, as was the case of the Tang, châu 州 (province) were the highest-ranking administrative units at the beginning of the Lý Dynasty, with some phủ 府 units that were honorific titles conferred upon important châu units. After that, however, phu became the highest-ranking administrative units, while châu came to designate mainly settlements of non-Annamese ethnic groups. ${ }^{12}$ In the late $12^{\text {th }}$ Century,

Tokyo: Soka Daigaku Ajia Bunka Kenkyu-sho (The Institute for Asian Culture, Soka University), 1987: 16-19), and Momoki (Chusei Daietsu, 17-19, 161-2) think SL was compiled not at the end but in the early phase of the Trần period. Foreign scholars (including Poliacoff and I) emphasize the value of SL, even though the original was carried away by the Ming invaders and only crude copies by the Chinese survive in modern times. On the contrary, Vietnamese scholars tend to stick to the orthodoxy of TT (completed in 1479 and recognized as official annals) as well as late early modern studies of historical evidence such as Lịch triều hiến chuoong loại chí 歴朝憲章類誌 by Phan Huy Chú and Khâm định Việt sư thông giám cuong muc 欽定越史通鑑綱目 by the historiography office of the Nguyễn Dynasty, regardless of their uncertain bases for the period before the $13^{\text {th }}$ century.

${ }^{9}$ Because TT and SL both contain few entries for most years, the date of the quoted record hereafter will be shown simply as TT-1010 (the year 1010 of TT) or SL-1115/1 (the first lunar month in the year 1115 of SL). Dates in the lunar calendar are converted to those of the Christian Era mechanically, regardless of the lag at the end of a year. The Chinese chronicle Xu Zizhi Tongjian Changbian 続資治通鑑長編 (hereafter CB, a chronicle of the Northern Song compiled by Li Tao 李壽) will be cited in the same way, even though it contains far more entries for each year.

${ }^{10}$ Henri Maspéro, "Études d'histoire d'Annam II: La géographie politique de l'empire d'Annam sous les Lí, les Trần et les Hồ ( $\mathrm{X}^{\mathrm{e}}-\mathrm{XV}^{\mathrm{e}}$ siècles)," Bulletin de l'École Française d'Extrême-Orient tome 16 (1916) fasc. 1, 41.

${ }^{11}$ Ibid., 30-31.

${ }^{12}$ Besides ordinary zhou 州, which were administrative units situated between xian 縣 (Vietnemese < huyện, district) and dao 道 (Vietnamese<đạo, circuit), there were two other kinds of zhou in Tang China, namely, autonomous regions of non-Han ethnic groups (jimizhou 覉糜州) and honorific titles conferred upon xian. In the case of Lý Đại Việt, there were only two types of châu: the jimi zhou type (ordinarily ruled by non-Annamese local chiefs called châu muc 州牧 or thủ lĩnh 首領, but sometimes governed by Annamese governors trị châu知州 when they were too fragmented or lacked powerful local leaders); and honorific titles conferred upon huyện 縣 units. The core area of the Red River Delta (under the jurisdiction of Đô hộ phủ 都護府) was divided into huyện units without founding châu units. Maspéro, "La géographie politique," 37-38. 
the entire territory of Đại Việt was divided into five phủ units, namely, Đô hộ phủ (covering the Red River Delta), Đại Thông phủ 大通府 (Northwestern hills?), Thanh Hóa phủ (Southern provinces), Phủ Lương phủ (Northeastern mountains) and Bắc Giang phủ 北江府 (the border area with Chinese Guangdong and Guangxi). ${ }^{13}$

Đào Duy Anh ${ }^{14}$ simply believed that the twenty-four lọ units recorded in TT-1010 were the highest-ranking administrative units. However, TT-1010 lists the names of only two provinces, Ái Châu and Hoan Châu, which were denominated as trại 寨 (military jurisdictions in the periphery?). Anh tried to identify the rest with two assumptions. First, there may have been many lọ units to which only one phủ (governed by trị phủ 知府 or phán phủ 判府) or châu (governed by tri châu 知州) belonged because the territory of Đại Việt was small. ${ }^{15}$ Therefore, a place name recorded as a phủ or a châu may have been equivalent a lọ unit. Second, the number twenty-four in TT-1010 may have copied the number at the end of the Lý period recorded in TT-1222. Anh listed twenty-four regions as units that were equivalent to $l \hat{\text { a }}$ and already existent by the end of the Lý. In mountainous areas, there were châu units of the jimizhou type governed by thủ lĩnh chiefs, which were on the same level as huyện units in the lowlands. In addition, there were units such as huoong 郷 and giáp 甲 in the lowlands (similar status to huyện), and trại 寨 and động 洞 in the mountains (similar to châu of the jimizhou type).

${ }^{13}$ Ibid, 30-31, 40. Maspéro made this identification mainly based on Lingwai daida 嶺外 代答, a Chinese source compiled c. 1178 that lists four phủ, 13 châu and three trại of the country of Annam, but he added the fifth phủ of Bắc Giang based on a misreading of SL. His identification of these phu appears to be overly speculative. Momoki, Chusei Daietsu, $247 \mathrm{n}$. 48,252 n. 65.

${ }^{14}$ Đào Duy Anh, Đất nước Việt Nam qua các đời-Nghiên cứu địa lý học lịch sủ Việt Nam (The Territory of Vietnam through Historical Periods: A Study on Historical Geography of Vietnam), (Hà Nội: Nhà Xuất bản Khoa học, 1964), 90-93. Despite his more inductive approach to research, Phạm Đức Anh, "Về tính chất tập quyền" still follows Anh's framework

${ }^{15}$ For the Trần Period, Maspéro wrote the same thing. See Maspéro, "La géographie politique," 45-46. 
Sakurai Yumio, ${ }^{16}$ who did not comment on Maspéro's work, criticized the systematic interpretation of Vietnamese scholars, not only because the 1010 event was not recorded in SL, but also because both TT and SL recorded few real names of lọ (see the Table below). In Sakurai's opinion, the lô system covering the entire territory during the Lý Period (before 1222?) was not effective, if it was not an invention of the compiler of TT. The highest-ranking units included lọ đạo, phủ and châu, the second ranking quận, huyện and trấn, the third ranking giáp, hương, thôn 村, ấp 邑 and $x \tilde{a}$ 社. Every place name was given a unit title quite arbitrarily, to the extent that the titles no longer functioned to designate a position within a unified administrative system. There were of course semi-independent châu units outside the Red River Delta, which derived from jimizhou units during the period of Chinese protectorate (usually governed by indigenous chiefs like châu mục or thủ lĩnh, but sometimes by trị châu governors who were despatched temporarily by the central government to secure strategic positions). Even in the Red River Delta, there remained semi-independent local powers (called châu or đạo) which would be the major actors in the civil war at the end of the Lý Period. The distribution of such hereditary local powers on the one hand and phủ and outer palaces (hành cung 行 宮) on the other suggests that the central court was able to control directly only limited areas, including the Thăng Long capital, Thiên Đức phủ (where the first emperor Lý Công Uẩn was reportedly born), the West floodplain and the lower delta.

Before reviewing these contrasting explanations through an inductive approach, we should remind ourselves of two features of the Chinese models that might have influenced the Lý system. First, when a place name recorded in the form of the title(s) of the governor/leader may include different categories of title: one indicating the person's real function/post, one indicating a nominal position corresponding to the person's bureacratic rank, or one indicating the person's peerage. Titles of each category can bear the place name with a unit title that corresponds to the official/peerage title. Such place names and unit titles can vary 
depending on a number of factors including the status and honor of the recipient and the literary tendency to employ ancient place names and/or unit titles (especially for the titles indicating the rank or peerage) as eulogistic denominations. A person can hold two or three real functions at the same time, including temporary tasks. Though records related to a person's promotion or biography may record all categories he held at the same time, ordinary records only mention the category corresponding to the event to be recorded. ${ }^{17}$ Second, according to the standard view in Japanese academia, the $l u$ (Vietnamese < lộ) under the Song Dynasty (960-1279) which inaugurated the lu system was basically a unit of superintendence (in military, judiciary and financial spheres), although its administrative function was gradually strengthened. $L u$ itself did not have its own office, and the post of a lu official was often held by a high-ranking fu or zhou official in the area which the lu supervised.

${ }^{17}$ For instance, according to Ngưỡng sơn LInh Xứng tự bi minh 仰山霊称寺碑銘 inscription (erected in 1126), Lý Thường Kiệt, a famous eunuch general, held the title of Trí Ái Châu Cửu Chân quận Thanh Hóa trấn chư quân châu sự 知愛州九真郡清化鎮諸軍州事 (director of the affairs of military troops and districts in Ái Châu = Cửu Chân quận = Thanh Hóa trấn? ) (Phan Văn Các and Claudine Salmon, eds., Văn khắc Hán nôm Việt Nam tập 1 (越南漢喃銘文匯編第一集 北属時期至李朝; Sino-Vietnamese Epigraphic Sources, vol 1: The Peiriod of Chinese Domination to the Ly Dynasty), Hà Nội: Viện Nghiên cứu Hán Nôm and École Française d'Extrême-Orient, 1998, 165). Both Ái Châu and Cửu Chân quận are old names of Thanh Hóa, probably employed as eulogistic names. Because this title indicates a military governorship, the real regional name Thanh Hóa must be accompanied by the unit title of trấn rather than phủ, which is related to civil administration. During the Trần Period, we can find a more complicated set of titles in Tiên Long sơn Kim Cương tự Hiển Diệu tháp bi văn 仙隆山金剛寺顕曜塔碑文 erected in 1367, Phan Văn Các et. al, ed., Văn khắc Hán nôm Việt Nam tập 2 (越南漢喃銘文匯編 第 2 集陳朝; Sino-Vietnamese Epigraphic Sources, vol 2: The Tran Dynasty), 2 vols (Hà Nội: Viện Nghiên cứu Hán Nôm; Jia Yi: Zhongzheng daxue wenxueyuan [嘉義 : 中正大学文学院], 2002), 478-9, which lists the full set of official and peerage titles of Khai Quốc đại vương Trần Cung Tịnh 開国大王陳恭靖, including titles related to local governorship such as Hoàng Châu Trường An phủ Nghê An phủ lộ đô nguyên soái 黄州長安府入安府路都元帥 (super-marshal of Hoàng Châu = Trường An phủ and Nghệ An phủ lộ?, a title probably indicating a military rank), sư trì tiết Nghê An phủ lộ Đại An hải môn trấn chư quân sự 使持節义安府路大安海門鎮諸軍事 (Military Commander of Đại An hải môn trấn of Nghệ An phủ lộ, a real post ?), hành Nghê An doãn 行入安尹(Provisional governor of Nghệ An(?), seemingly not a real post).

${ }_{18}$ Kobayashi Takamichi. "Sodai no koiki-kukaku lo nitsuite (On the Large Jurisdiction of 
Then, how should we understand the lọ system of Đại Việt during the Lý Period? Though few specific lọ units and lọ officials are named in the annals, the following records appear to show the character of the $l \hat{o}$.

In this year, the whole country suffered a large famine. [Emperor Thái Tông] issued an edict ordering Nguyễn Châu of xu mật viện 枢 密院 (Ministry of military administration?) to let runaways in lọ units 諸路逃人, whenever they recognize a local bridge or a route, make a filling there with wooden tablet on the top of it for the convenience of traffic in all directions (TT-1042).

Robbers rebelled. [Emperor Cao Tông] issued an edict ordering to draft healthy male adults to stuff them into military troops. The $l \hat{o}$ officials 路官 [were ordered to] command them to arrest robbers (TT-1207).

Divided the whole country into 24 lọ circuits. [In every circuit] a Circuit Princesse 路分公主(?) settled there, and bond servants and slaves, and soldiers in the circuit as well, were divided into giáp troops (TT-1222).

In the Trần Period, lọ official(s), trấn official(s) and official(s) of sát hải sú 察海使 (maritime inspector?) were appointed at the same time at the famous trading port of Vân Đồn 雲屯 (which itself was called Vân Đồn trấn) (TT-1349). It is quite likely that the lọ in Đại Việt was originally not a general administrative unit but a unit of superintendence which covered other administrative unit(s). Though lọ officials under the Trần had broader administrative functions, ${ }^{19}$ those under the Lý (and officials of đạo which reappear in the end of the Lý Period as well) seem to have had only military and policing functions (like anfushi 安撫使 of the Song), as Maspéro asserted. ${ }^{20}$ This can explain why phü

Lu in the Song Era)," Shiteki 25 (2003).

${ }_{19}$ Momoki, Chusei Daietsu, chap. 8.

${ }^{20}$ Such records as "Went to Hồng Lộ 烘路 to train soldiers" (SL-1209) and "General of Khóai Lộ 快路将軍”(SL-1215/1) may also show the military nature of lọ units. A military draft supervised by Tô Hiến Thành and Phi Công Tín (1160), an imperial order to Phi Công Tín, leading one hundred thousand soldiers, to pacify deserters from the army who plundered inhabitants (TT-1163) and another military draft (TT-1179) may also have been recorded as the tasks of $l o ̣$ officials. 
and châu units appear in the Table far more frequently. ${ }^{21}$ They must have been recognized as general units of the highest rank.

Because the line and staff of the Lý bureaucracy must have been small and primitive compared to the Chinese-modeled large and complicated bureaucratic systems, ${ }^{22}$ it was also possible that the jurisdictions of a lọ and a phủ or châu overlapped, as Đào Duy Anh thought. If so, more local governors probably held posts of both lọ and phủ or châu than in the Song. Otherwise, only one suitable title may have been actually conferred upon such a governor according to the political situation and the rank, status or fame of the appointee. ${ }^{23}$ Moreover, as will be discussed again in the Conclusion, the local unit was perceived as an indicator of political power rather than a territory, and the governor's title (even that of a real function) often existed without an official post and facilities. In this situation, an event in a locality could be recorded with a unit name following any of the overlapping titles conferred upon the area or to its leader, or with its customary denomination. In other words, an area could be called phủ, châu (more often because these denominations had long been employed) and sometimes lọ (though it had not yet taken root) depending on the context of events and records. Such a situation must have led Sakurai to find "arbitrary denominations", though it does not necessarily exclude the effectiveness of the system itself. In sum, the three interpretations in question each explained a single issue from a different angle.

${ }^{21}$ Phạm Đức Anh, "Về tính chất tập quyền" also listed nine phủ units (p. 9) and 52 châu units (pp.19-20 n. 27).

${ }^{22}$ Nguyễn Thừa Hỷ, "Về cấu trức xã hội chính trị thời Lý-Trần" (The Socio-Political Structure during the Lý-Trần Period)," in Viện Sử học, Tìm hiểu xã hội Việt Nam thời Lý-Trần, $1981,332$.

${ }^{23}$ For the governor of $l o ̣$ and phủ or châu during the Trần Period, Maspéro ("La géographie politique," 45-46) also wondered whether a local governor was appointed to both sort of posts or received only one title as governor of these units depending on the level of honor accorded by the central government. 


\section{The Hierarchy of Local Units}

How should we understand the hierarchy among various local units? First of all, were those units classified into three levels as was the case during later dynasties?

Maspéro failed to show concrete evidence that the five phu units in the late Lý Period covered the whole territory of Đại Việt institutionally, ${ }^{24}$ though they may have had a general mission to control surrounding areas. Phu still appears to have been a unit to which an important châu was promoted, as Ái Châu was renamed Thanh Hóa phủ sometime during 1061 to $1111^{25}$ and Hoan Châu may have been renamed Nghệ An phủ in 1101. ${ }^{26}$ Maspéro's clear-cut distinction between châu (found in mountainous area) and huyện (in the Red River Delta) is also doubtful. Among huyện units in the Table in the end of this paper, some can be found in mountainous area as Liện huyện (TT-1039) or Hạ Liện huyện (SL-1062) in Lạng Sơn or Cao Bằng, and Bác Như huyện (TT-1141) in Thái Nguyên or Bắc Cạn. ${ }^{27}$ In the Red River Delta, only a few huyện units appear in Table 1, as Thái Bình huyện (TT-1015, in present-day Vĩnh Phúc or Hà Tây), Binh Hợp huyện (TT-1214, in Hà Tây) and Yên Duyên huyện (TT-1216, in Hà Tây.), although other huyện units appear in notes of TT, in which Lê Văn Hưu or Ngô Sĩ Liện may have employed unit titles under the Trần or the Lê. $^{28}$ On the contrary, as Sakurai pointed out, it is possible that some of the local powers that scrambled for hegemony at the end of the Lý Period bore the title châu, such as Đằng (SL/TT-12o8; SL-1209), Khóai (SL-1209) and Hồng (TT-1209; TT-1212).

${ }^{24}$ Momoki, Chusei Daietsu, 252 n. 65.

${ }^{25}$ The date may have been during the latter half of the reign of Thánh Tông (1054-72), when Lý Thường Kiệt was dispatched to Thanh Hóa and Nghệ An to supervise officials and people there (TT-1111) or when he governed Thanh Hóa during c.1082-1101 (Hoàng Xuân Hãn, Lý Thuoọng-kiệt, Lịch sủ Ngoại giao Triều Lý [Ly Thuong Kiet; The Diplomatic History of the Ly Dynasty], Hà-nội: Sông Nhị, 1949, 368).

${ }^{26}$ SL-1101 states "Change Hoan Châu to Nghệ An phủ". This is the only record in the annals that treats Nghệ An as a phủ, while many records after 1011 call Nghê An châu. However, the tombstone inscription of Đỗ Anh Vũ , who seized the power under the reign of Anh Tông (1137-75), mentions Nghệ An phủ. See note 55 below.

${ }^{27}$ Momoki, Chusei Daietsu, 253.

${ }^{28}$ Ibid., 253. It is possible that the huyện units during the Lý Period were of the same rank as châu, rather than below châu, although the relationship between huyện and ấp is problematic as will be discussed below. 
In the lowland, titles like hưong 郷 and giáp 甲 ${ }^{29}$ appear to have been more popular than huyện for the unit under the provincial (highest) rank. Such units as hương and giáp may have been units whose position had not yet been differentiated into the middle rank (like huyện) and the basic or lowest rank (like xã in the later eras).$^{30}$ Âp 邑 units, which often appear at the end of the Lý Period, may not always have been elegant expressions of huyện as was the case in China. ${ }^{31}$ Nghĩa Trụ âp (SL-1215/2), whose leader, Chu Đình, supported Nguyễn Nộn (an anti-Trần leader in Bắc Giang), seems to correspond with Nghĩa Trụ hương recorded in Thiền uyển tập anh (6ob). ${ }^{32}$ The most important among the “various áp of the Khóai region 快諸邑”(SL-1211/6) must have been Khóai Hương (SL-1215/3). "Various ấp of Phong Châu 峯州 諸属邑” (SL-1217) may have included Cam Gía giáp (TT-1117, present-day Đường Lâm in Hà Tây), where a certain "general of Cam Gía 甘蔗将軍 appeared (SL-1214/4). It is noteworthy that these $\hat{a} p$ all had military functions. This implies that below the level of provincial units, there were customary units that had not yet been differentiated in terms of administrative hierarchy and whose politico-military power had not yet been dissolved or reorganized administratively.

In the southern provinces, place names are commonly recorded with the names of the province and the huoong or giáp, as Đãn Nãi giáp of Aí Châu (TT-1034), Đỗ Gia hương in Nghệ An châu (TT-1128), and Cao Xá giáp in Diễn Châu (TT-1198). In the

${ }^{29}$ Annanzhi (An Nam chí 安南志, commonly called An Nam chí nguyên), a record of the Ming rule of Đại Việt, quotes the Ngọai Ký annals of “the False Việt”偽越外紀) to tell the origin of huong and giáp, according to which hương units were founded under the xian (huyện) rank during the late Tang Period but were replaced with giáp under the Liang of the Five-Dynasty Period. So far, no confirmatory Tang or Five-Dynasty record has been found.

${ }^{30}$ Some place names bearing the title huoong, such as Siêu Lộai hương (TT-1068; SL-1115) and Thanh Oai hương (TT-1207), would bear the title huyện in the early modern era. See Sakurai 1987: 164-6. Pham Đức Anh ("Về tính chất tập quyền," 10) regarded huyện and hioong as units of the same rank, under which giáp was situated.

${ }^{31}$ In the case of Binh Hợp, it was called huyện in TT-1214 but ấp in SL-1216/8.

32 Nghĩa Trụ đạo (SL-1214) was probably a military jurisdiction centering on Nghĩa Trụ hương. See Momoki, Chusei Daietsu, 252 n., 63. 
Red River Delta, a similar method of recording can be found, as Tín Hương of Đõ Động Giang ${ }^{33}$ (TT-1032). Religious sources related to the Lý-Trần Period also usually record place names as a combination of names of higher and lower rank. In Thiền uyển tâp anh, a collection of biographies of Zen priests compiled in the $14^{\text {th }}$ century, for instance, ${ }^{34}$ five names of huo'ng are recorded in combination with the name of Thiên Đức phủ as native or working places of priests. A number of quận 郡 units appear, as Phúc Đường quận 福堂郡, Mãn Đầu quận 満斗郡 and Tiên Du quận 僊 遊郡, some of which are accompanied by hurong names like Phủ Đồng hương in Tiên Du 僊遊扶董郷 $(4 a 、 9 b 、 66 b)$ Thử Hương in Thanh Dật hương 清溢郡蜍郷 (49a) and Tháp Bát hương in Mãn Đầu quận 満斗郡塔鉢郷 (62b). Aside from the question of whether these quận names were merely elegant denominations (of huyện rather than châu?) in non-official sources, the prevailing custom seems to have been to indicate a place name with a combination of two names (one of higher rank as phủ, châu or quận and the other of lower rank as hương or giáp) was prevalent. Place names below hưong and giáp were seldom recorded, ${ }^{35}$ probably because the state power could not penetrate easily into the level of natural villages. It is well known that, following the rise of Lý Công Uẩn, his native place Cổ Pháp hương was first promoted to the rank of châu, and then to Thiên Đức phủ. At least in the sphere of custom or reality, only two levels of denomination appear to have been discerned, namely, that of higher rank (including phủ, châu, and quận) and that of lower rank (including hương, giáp, and trưòng ${ }^{36}$ ).

${ }^{33}$ The term Giang 江 originally meant a river but often indicated a region where the river flowed. An Nam chí lược (vol.1, the entry of Thanh Hóa phủ lộ), a topography of early Trần Đại Việt, explains that units under the phủ lộ of Thanh Hóa were called giang, truoòng 場, giáp or xã. However, the name Đỗ Động giang in the Red River Delta rather appears to be the highest-ranking regional name.

${ }^{34}$ See Momoki, Chusei Daietsu, 234 (Table 6-4), 253-7. For the textual study of Thiền uyển tập anh, see Cuong Tu Nguyen, Zen in Medieval Vietnam: A Study and Translation of the Thiền Uyển Tập Anh (Honolulu: University of Hawai'i Press, 1997).

${ }_{35}$ TT and SL mention some $x \tilde{a}$ and thôn units as shown in Table in the end of this paper, while Thiền uyển tập anh mentions such combined names as Long Chiển in An Các hương 安 格郷壠锂 (21b) and Tư Lý in Kim Bồi hương 金牌郷思理 (2b).

${ }_{36}$ Trường (also pronounced as Tràng) was first recorded in the annals in 1119 as Khóai Trường (TT). Kuang Lang trường (TT-1128), which reportedly presented drifted Song ships, 


\section{The Titles of Local Governors}

Next, let us examine who (what kind of personnel) governed these units. While personal names are not recorded with the titles of the governors of lower-ranking units such as huyện, hương and giáp, ${ }^{37}$ a number of governors of various higher-ranking units are recorded by name and title. As mentioned above, however, we know only a few personal names of lọ officials, that is, Nguyễn Đường 阮堂 and Nguyễn Thử 阮的此, both of whom are called Khoái Lộ generals (Khoái Lộ tướng quân 快路将軍) in SL-1215/1. Military commanders (tướng or tướng quân) are also recorded with the units as $₫ a o^{38}$ in the records of the civil war at the end of the Lý Period. The relationship between lọ and đậo (and the above-mentioned $\hat{a} p$ units, which are also recorded as military powers) is unclear. Records of the heads of trai ${ }^{39}$ suggest

appears to have been located in the famous port complex of Vân Đồn. Thiền uyển tập anh mentions a certain Đại Thông trường (70b). This name may have been related to the ferry Đại Thông đô 大通渡, the name of which was incised in a brick excavated at the 18 Hòang Diệu site of Thăng Long Imperial Citadel. During the Trần Period, such names as Bát Tràng 鉢場 (a famous production center of ceramics, recorded in TT-1352) and Vĩnh Ninh trường 永寧場 (the bricks of which were excavated both in Thăng Long and Hồ citadels) were recorded. Judged from these, truòng appears to indicate centers of certain functions, such as handicrafts and transportation, that were controlled directly by the central court.

37 A chủ đô 主都 (head) of Tất tác giáp is recorded in TT-1120. Whether this giáp was a functional organization (for the production of lacquer) without a fixed territory or a local community is not known. The quản giáp 管甲(the chief of a giáp?) recorded in TT-1025 without a place name appears to indicate an official rank rather than an actual position of a giáp chief.

38 Tướng quân of Bắc Giang đạo 北江道将軍 (see also note 35 below) and Phủ Lạc đạo 扶楽道 are both recorded in SL-1214/6.

${ }^{39}$ Lý Đài Giai 李台偕, who had been quản giáp, was appointed as the head of Bà Hòa trại (TT-1025). Trần Thiềm, chủ đô of Tuyên Minh trại 宣明寨主都陳蟾, attacked the rebel Thân Lợi 申利 in the vanguard together with Tô Tiệm 蘇漸, an imperial guard of thị vệ đô 侍 衛都 (TT-1141). These records at least imply a control by the central court, if these heads were not dispatched from the center. In the case of Hà Cao 何高, the chief of Qui Hóa trại 帰 化寨, against which The Trần family made an expedition in 1220, appears to have been a powerful local chief (possibly related to the Hà family in Vị Long châu) because the areas of Thượng Nguyên lộ and Tâm Đái Giang (the area of the confluence of the Red River, the Đà River and the Lô River) were all pacified after his death (SL). For the charater of trại, see also Phạm Đức Anh, "Về tính chất tập quyền," 10). 
that trai may also have been an official unit set up in the periphery (with a military function?) by the central court, rather than a customary local community. ${ }^{40}$ Yet, its relationship with $l \hat{o}$ is also unknown.

Regarding the châu, the unit that is recorded most frequently, four titles are recorded, namely, thú sư刺史, thu lĩnh 首領, châu muc 州牧 and tri châu 知州. ${ }^{41}$ It is noteworthy that persons bearing the title thu' sü (Chinese < cishi) appear only in Chinese records ${ }^{42}$ of tributary missions, mainly from the Former Lê to the early Lý Periods, such as Lương Nhiệm Văn 梁任文 in 1010 (thú sử of Trường Châu, former Tang province in the lower Red River Delta), Lý Nhân Mỹ 李仁美 in 1012 (thứ sứ of Diễn Châu), Lý Công Hiển in 1027 (thú sử of Hoan Châu), Lý Ốc Tiên 李偓佺 in 1031 (thư sư of Phong Châu) and Sư Nhật Thân 師日親 in 1031 (thú sư of Ái Châu). Whether these persons really came from those provinces is unknown, because they are recorded in the annals of Đại Việt only with the title viên ngoại lang 員外郎, the title of an imperial personal attendant in China before the Tang. Whatever the case, there is no evidence that these titles were conferred upon the envoys by the Chinese side. It is likely that the ruler of Đại Việt (recognized by China as merely the ruler of Jiaozhou or Giao Châu in the Red River Delta) sent tributary envoys with ad hoc titles in order to demonstrate his rule over former Tang provinces outside Jiaozhou. ${ }^{43}$ If so, thú sú may have

40 Though it is not clear how he regarded the nature of these units, Phan Huy Chú wrote "military posts outside the capital [were set] in lộ, trấn and trại, where governmental soldiers were stationed to defend"(Lịch chiều hiến chương loại chí vol. 13, 5a). See also Geng Huiling 耿慧玲,Yuenan shilun: Jinshi ziliao zhi lishi wenhua bijiao 越南史論一金石資料之歴史 文化比較 (Historical Research in Vietnam: Historical and Cultural Comparisons of Epigraphic Sources) (Taipei: Xin Wenfeng Chuban Congsi, 2004), 57.

41 See Momoki, Chusei Daietsu, 235-6: Table 6-5. Probably "Lý Bất Nhiễm, Count of Nghệ An châu 入安州伯李不染”（TT-1214） was also a local chief of Nghệ An with the title of count. Peerages conferred on local chiefs are also recorded in SL-1210/11 (Trần Tự Khánh, minh tự [a kind of lower peerage] of the Lower Region 順流明字陳嗣慶) and SL-1218/2 (Bạch Lãng, minh tự of mountainous barbarian in Ma Luận sách 麻論柵山獠明字白浪). Nguyễn Nộn 阮嫩 was promoted from the general of Bắc Giang đạo 北江道将軍 to the duke of Bắc Giang 北江侯 (SL-1214/6) and then to the prince of Bác Giang 北江王 (SL-1216/5).

${ }^{42}$ The most important ones are the official history of the Song (Songshi 宋史), the recollected statutes of the Song (Songhuiyao jigao 宋会要輯稿) and CB.

${ }^{43}$ For information on these thú sü, see Momoki, Chusei Daietsu, 142-3, and see also Wolters, "Le Van Huu's Treatment," 210-1. 
been a title for use exclusively in diplomacy. However, SL-1056 tells that the title grand chief (đại thu linh 大首領) was replaced with thú sü. In the Han China, cishi was often renamed zhoumu (Vietnamese < châu muc). Therefore, the title thư sư may have been a eulogistic form of the titles of local chiefs. ${ }^{44}$

The category thủ linh appears to have been divided into several ranks, such as đại thủ lĩnh (grand chief) and tiểu thủ lĩnh 小首 領 (petty chief), as was the case in Tang China ${ }^{45}$. TT-1129 calls Hà Văn Quảng 何文広 a grand chief of Tây Nông châu (present-day eastern Thái Nguyên), while TT-1124 mentions both thư lĩnh (Dương Tự Hưng 楊嗣興) and tiểu thủ lĩnh (Mạc Hiền 莫賢) of Quảng Nguyên châu (present-day Cao Bằng) at the same time. TT-1145 mentions five thũ lĩnh chiefs of Bố Châu 蒲州首領五人. There could be plural thủ lĩnh chiefs in a local unit. ${ }^{46}$ In contrast, châu muc only appear in important provinces as a single chief. Persons bearing the title châu muc are recorded as chiefs of such provinces as Bình Lâm châu in TT-1014 (present-day Cao Bằng), Lạng Châu in SL and TT-1029, SL-1072 and SL-1167 (Bắc Giang and Lạng Sơn), Vĩnh Yên châu in 1033 (on the border of Quảng Ninh with China), Phong Châu in 1036 (Vĩnh Phúc region), Thượng Oai in 1036 (unidentified), Vị Long châu ${ }^{47}$ in 1082

${ }^{44}$ According to Thiền uyển tập anh, Chân Không thiền sư 真空禅師 was patronized by Lý Thường Kiệt and Lạng Châu thứ sử tương quốc Thân công 諒州刺史相国申公(65a). It is not clear whether this thú sủ was a real title or a eulogistic form of châu muc.

${ }^{45}$ For the Tang system, see Furuhata Toru, “Todai 'shuryo' gogi ko--Chugoku seishi no yorei o chusin ni--(A Study of the Meanings of shuling in the Tang Period, Focusing on the Illustrations in Chinese Official Histories)," Tohokudaigaku Toyoshi Ronshu (Tohoku University Pepers on Asian History) 11 (2007): 34-37. The grand chief was treated as official rank four or five, while the petty chief rank six.

${ }^{46}$ Judged from TT-1141, which mentions a thủ lĩnh of Kim Kê động, thủ linh titles were not conferred exclusively on the chiefs of a unit bearing the title châu. Nevertheless, Ngụy Bàng 魏滂, a chief of Ma Sa động, is simply called "head" (động trưởng 洞長) in TT-1119. Động and sách are thought to have been basic units in the mountainous area, which could be promoted to the rank of châu.

${ }^{47}$ The chief of Vị Long châu who rebelled in 1013 is called thủ lĩnh (TT-1013), while the chief who married with a Lý princess is called châu mục (SL, TT-1082). As Maspéro ("La géographie politique," 37) pointed out, the status of châu muc must have been higher than that of thu linh chiefs. 
(Tuyên Quang region), Chân Đăng châu in 1113, 1132 and 1140 (Phú Thọ region). It is well known that families of châu muc such as the Thân 申 in Lạng Châu, the Lê 黎 in Phong Châu and Chân Dăng châu and the Hà 何 in Vị Long châu had close marriage ties with the Lý imperial family, having both received princesses from and offered women to the central court ${ }^{48}$.

The conventional view that thủ lĩnh and châu muc chiefs were "indigenous autonomous chiefs" of "non-Viet ethnic minorities" in remote areas is not entirely adequate. First, not only châu muc but also thu linh could take part in the affairs of the central court. Sư Dụng Hòa 師用和 recorded in TT-1033 as Vĩnh Yên châu mục is identical with Soái Dụng Hòa 帥用和 recorded in Songshi in 1040 as a tributary envoy. Dương Cảnh Thông 楊景通 was the châu mục of Lạng Châu in 1072 (SL) but recorded in CB-1084 as governor of Quảng Nguyên châu 知広源州 in 1084. Dương Tự Minh, a thủ lĩnh of Phú Lương phủ (or châu), was married with two imperial princesses and entrusted with the affairs of Khê động (minority settlements) on the border 沿邊渓洞 公事 (TT-1143). He was killed because he participated in an unsuccessful coup at the court against Đỗ Anh Vũ, who held the real power of the court (SL-1048, TT-1150). Second, ethnic boundaries in this period do not seem to have been as rigid as in later dynasties $^{49}$. Otherwise, it might have been difficult for the emperor to send his own princesses to the "barbarian" chiefs. The Lê family in Phong Châu and Chân Đăng châu claimed to be descended from Ngự Man vương Đinh 禦蛮王釷, the fourth son of the em-

${ }^{48}$ For the gender analysis of the Lý imperial family, see Momoki Shiro, "Gia đình của các vua nhà Lý và sự xuất hiện của vương triều phụ hệ (The Family of Ly Emperors and the Emergence of a Patrilineal Dynasty)," in Đại học Quốc gia Hà Nội - Trung tâm Khoa học Xã hội và Nhân văn Quốc gia (Vietnam National University, Hanoi and National Center for Social Sciences and Humanities), Việt Nam học, kỷ yếu hội thảo quốc tế lần thư nhất, Hà Nội, 15-17.7.1998. tập I (Vietnamese Studies: Proceedings of the First International Congress, Hanoi, 15-17 July, 1998, vol. 1), (Hà Nội: Nhà Xuất bản Thế giới, 2000); do, "Nhũng người đàn ông ngoài hoàng gia ở triều đình nhà Lý (Males From Outside the Imperial Family in the Lý Court).” In Ủy ban Nhân dân Thành phố Hà Nội, 1000 năm vương triều Lý, 2009.

${ }^{49}$ TT-1148 tells, "Issued an edict to prohibit thu lĩnh and quan lang 官郎 chiefs of mountainous barnbarians in barbarian villages in the two trấn areas of Đại Thông and Quy Nhân 大通帰仁二鎮蛮里山獠首領官郎 from visiting the capital without reason. This implies "barbarian" chiefs often called on the capital, as the famous Nung Trí Cao visited Thăng Long in 1044 (SL/TT) to receive in audience with Thái Tông. 
peror Lê Hoàn (r. 980-1004). They not only received imperial princesses but also presented women to the court, among whom was the mother of the emperor Anh Tông (r. 1137-75), who became the empress dowager after her son ascended the throne and supported her lover Đỗ Anh Vũ's seizure of real power. ${ }^{50}$ Such would have been impossible if châu mục had merely been the chief of an ethnic minority and there had been an absolute boundary between the Kinh people and other minorities.

Records of the title tri châu are concentrated in Nghệ An, the southern frontier through which strategic routes to Champa and Laos passed (TT-1041; TT-1073; TT-1131; SL/TT-1203; SL-1218). In addition, tri châu governors of Thượng Nguyên châu (present-day Bắc Cạn?) and Quảng Nguyên châu (the case of Dương Cảnh Thông mentioned above) are recorded in CB-1084 and CB-1086 respectively. The title trí Lang Châu quân sụ 知諒州軍事 (director of military affairs of Lạng Châu) was conferred in 1128 (SL) on Lý Sơn 李山, the father of the queen of Thần Tông, and trí Nghê An châu quân sụ was conferred on a eunuch named Phạm $\mathrm{Du}$ 范猷 in 1208 (SL). Apparently, the tri châu governors (and tri châu quân sư directors too) were appointed only temporarily on special occasions in provinces where châu muc or thủ lĩnh chiefs existed $^{51}$. The appointment of trí Nghê An châu was made on such occasions as three years before Thái Tông's expedition to Champa (prince Lý Nhật Quang 李日光, TT-1041) and three years after the invasion of Cambodia (Mậu Du Đô 牟兪都, a close attendant of Thần Tông, TT-1131). The appointment of Lý Đạo Thành 李道成 (TT-1073) is usually thought to have been a relegation after the ascendance of Nhân Tông (r. 1072-1128). Lý Sơn's appointment

${ }^{50}$ Concerning the marriage ties between the Lý and the Lê families, see Momoki, "Gia đình của các vua nhà Lý" and Geng Huiling, Yuenan shilun, 80-92. About Đỗn Anh Vũ, see Taylor, "Voices Within and Without," in Essays into Vietnamese Past, ed. Keith W. Taylor and John K. Whitomore (Ithaca: Cornell University Press, 1995) and Momoki, "Nhũng người đàn ông."

${ }^{51}$ A trí Nghê An châu and a Nghệ An châu mục are recorded at the same time in SL-1203/7. 
was, of course, a reward, while Phạm Du's appears to have meant eviction from the court. Appointments were not always made based on the necessity in the locale itself. The appointee could be an imperial family member, a close aid of the emperor including a eunuch or a powerful local chief (not confined to ethnic Kinh people, judged from the case of Dương Cảnh Thông). It is questionable to what extent these tri châu persons could play a different role from indigenous chiefs to enhance centralized administration.

Except for prince Khai Quốc vương Bồ 開国王菩 who was "stationed" at the former capital Hoa Lư (TT-1013), phủ governors are only recorded in the $12^{\text {th }}$ century in Thanh Hóa phủ and Phú Lương phư ${ }^{52}$. Along with the record of Dương Tự Minh, in which he is referred to as thủ linh of Phú Lương phủ, there are other records of high-class officials who governed a phu, though it is not clear whether they actually assumed the post at the locality or entrusted a representative with this function. Whatever the case, Lý Thường Kiệt with the title Thái Bảo 太保 supervised officials and people of Thanh Hóa and Nghệ An under the reign of Thánh Tông and again dominated Thanh Hóa during c. 1082-1011. ${ }^{53}$ Thái uy ${ }^{54}$ 太尉 Dương Anh Nhi 楊英珥 dominated (領) Thanh Hóa phủ (TT-1132). Thái uy Đỗ Anh Vũ “went to Phú Lương phủ to

${ }^{52}$ Songshi (vol. 488) and Songhuiyao jigao (the part of fanyi 蕃夷, vol. 4: the account of Jiaozhi 交趾) state that a “đô hộ phó sứ 都護副使 (vice-governor of Đô hộ phủ) named Nguyễn Thủ Cường 阮守疆 came to China together with a thú sủ named Lý Khoan Thái 李 寛太 as tribute envoys in 1022. Thử Cường's title may have been employed only for diplomatic purposes with China as the title thứ sử. Besides, sĩ su 士師 of Đô hộ phủ is recorded (TT-1037; TT-1067; SL-1211/1). Đào Duy Anh (1964: 92) regarded sĩ su as the governor of the capital. However, TT-1037 (There were many doubtful lawsuits, which the si su couldn't decide) and TT-1067 (Appointed Ngụy Trọng Hòa 魏仲和 and Đặng Thế Tư 鄧世資 as Đô hộ phủ sĩ sư and transferred ten secretaries to the post of jail supervisors 按獄吏), and the records of amnesties granted to the "prisoners of Đô hộ phủ" (SL-1072; SL-1097; TT-1128; TT-1130) all sugest that Đô hộ phủ during the Lý Period was a court or a jail. Lingwai daida of the Song (the entry of the country of Annam) mentions a building with a plate of Đô hộ phủ, which may indicate the building of court/jail.

${ }_{53}$ See notes 17 and 25 above.

${ }^{54}$ During the Lý Period, the titles of prime ministers followed the ancient Chinese model, such as thái su 太師, thái phó 太傅, thái bảo 太保 and tháy uy 太尉. See Fujiwara Riichiro, "Betonamu Richin-cho kansei ko, saisho seido ni truite (A Study of bureaucratic organization in Vietnam during the Lý-Tràn Period, on the system of prime ministers)," Siso (Kyoto Women's University) 44, 1987: 4-9, and Nguyễn Duy Hinh, Văn minh Đại Việt (The Civilization of Đại Việt), Hà Nội: Nhà Xuất bản Văn hoá-Thông tin và Viện Văn hoá, 2005: 460-1. 
evaluate officials and fix the number and items of family registers" (TT-1147). ${ }^{55}$

Unique titles for governors accompanied by terms such as thủ 守 and phán 判 are also recorded. ${ }^{56}$ Lý Hiến with the title trung thu 中書李献 (TT-1125) and Nguyễn Quyền with the title trung thu hỏa 中書火阮権(TT-1149) are both recorded as thủ Phú Lương phủ. Đỗ Nguyên Thiện with the title nội thường thị 内常侍 杜元善 (TT-1127) , Lương Cải with the title ngụ khô thu gia 御庫 書家梁改(TT-1130) and Dương Chưởng 御庫書家楊掌 with the title ngụ khô thu gia (TT-1135) were appointed as thủ Thánh Hóa phü. Phạm Tín 范信, who also held the title ngụ khô thu gia, was appointed as phán Thanh Hóa phủ (TT-1127). According to the system of the Tang and the Song, shou (Vietnamese $<$ thü) indicated a post higher than the appointee's rank, while fan (Vietnamese < phán) indicated the contrary case. In pre-Tang China, the title zhongshu (Vietnamese < trung thu') indicated an imperial secretary, while nội thưòng thị was a Tang post of eunuch who was a close aid of the emperor. Thu gia is recorded from the reign of Thánh Tông on for secretaries of the Lý emperor, while ngụ khô must have meant the imperial treasury. The term hỏa (and its head hỏa đầu 火頭) often appears in the records of the Lý-Trần Period to inidicate the units of such people as palace guards, secretaries and miscellaneous imperial court servants. ${ }^{57}$ Đỗ Nguyên

55 According to his tombstone “Cư Việt quốc Thái uy Lý công thạch bi minh tự 鉅越国 太尉李公石碑銘序 (Phan Văn Các and Claudine Salmon, eds., Văn khắc Hán nôm Việt Nam tập 1: 190), "three phủ units of Nghệ An, Thanh Hóa and Phú Lương were all lands where Anh Vũ was enfiefed."

${ }^{56}$ Đao Duy Anh (Đất nước Việt Nam qua các đời, 92) wrote that the governor of phủ during the Lý Period was called tri phủ 知府 or phán phủ, probably based on the speculation of Lịch triều Hiến chưong lọai chí. Of course, thủ phủ and phán phủ discussed below are all variants of tri phủ. However, the title tri phủ itself is recorded only in Bảo Ninh Sùng Phúc tự bi 保寧崇福寺碑 (Phan Văn Các and Claudine Salmon, eds., Văn khắc Hán nôm Việt Nam tập 1: 190), which tells that Hà Di Khánh 何彞慶 (who is called Vị Long châu mục in SL/TT-1082) governed ("trí") Vị Long châu.

${ }^{57}$ Concerning the terms that indicated imperial service units and their heads, see Momoki, Chusei Daietsu, 94-5, 107-9. See also Nguyễn Duy Hinh, Văn minh Đại Việt, 460-1, and Geng Huiling, Yuenan shilun, 471-2. 
Thiện was given the title deputy prime minister (tham trí chính sư 参知政事) together with the title thủ Thánh Hóa phủ. Their appointments aside, however, the only remaining records of above-mentioned persons, including Thiện, concern the moves of Phạm Tín (TT-1129) and Dương Chưởng (TT-1137) to the post of viên ngoai lang. Compared to imperial princes and high-ranking officials who governed châu or phü, these "nameless" officials are likely to have been controlled tightly by the emperor through personal patronage. Through these officials, in the first half of the $11^{\text {th }}$ century, the imperial power may have enforced more stable rule in strategic regions outside the Red River Delta such as Phú Lương and Thanh Hóa. ${ }^{8}$

\section{NON-INSTITUTIONAL CHANNELS OF LOCAL RULE}

\section{Imperial Tours and Outer Palaces}

During the first three reigns (Thái Tổ, Thái Tông and Thánh Tông), the Lý emperors and imperial princes often had to lead expeditions in person to suppress disobedient châu or other units. ${ }^{59}$ Subjugation of the regions outside the Red River Delta

${ }^{58}$ Soldiers of Thanh Hóa phủ were dispatched to escort a Chama prince back to the country (SL-1152), to suppress rebels of Cổ Hoàng giáp in Thanh Hóa (SL-1192) and Đại Hoàng in Ninh Bình region (SL-1203/9). Soldiers of Thanh Hóa were also ordered to suppress Tức Mạc (the Trần family) (SL-1210). When the then prime minister Đàm Dĩ Mông 譚以蒙 attacked the rebels of Đại Hoàng, he brought “Phú Lương archers 富良驽手” into battle (SL-1205). These imply that the Lý government relied much on the military forces from these two phu units. In the case of Thanh Hóa, the record in TT-1228 of "the former system" of detailed categorization and registration of manpower in Thanh Hóa phủ in units of $x \tilde{a}$, which appears to have been universarized after the Trần Period, may also support the view of intensive rule enforced in Thanh Hóa in the $12^{\text {th }}$ Century.

${ }^{59}$ During the reign of Thái Tổ (1009-28), for instance, Thái Tổ himself made expeditions to Cử Long 莒隆 in Aí Châu (SL/TT-1011), Diễn Châu (SL-1012) and Vị Long châu (SL/TT-1013), while prince Dực Thánh vương 翊聖王 made expeditions to Kim Hoa bộ 金華 歩 (SL/TT-1014), châu units of Đô Kim, Vị Long, Thường Tân and Bình Nguyên(together with Vũ Đức vương-TT-1015) and Như Hồng trại 如洪寨 (TT-1022) ; The crown prince Khai Thiên vương 開天王 made expeditions to Bố Chính trại (SL/TT-1020), Phong Châu (SL/TT-1024); Diễn Châu (SL/TT-1026) and Tắt Nguyên châu (SL/TT-1027); Prince Khai Quốc vương made an expedition to Đô Kim châu (SL/TT-1024); Pronce Đông Chinh vương 東征王 made an expedition to Văn Châu (SL/TT-1027). See Momoki, Chusei Daietsu, 229-30: Table 6-1. 
required demonstrations of the military power and charisma that the emperor and his princes possessed. From the reign of Nhân Tông (1072-1127) till the end of the $12^{\text {th }}$ century, however, local rebellions are seldom recorded, although every emperor ascended the throne in his infancy. Both the central government and its rocal rule were apparently more stable than during the first stage of the Lý dynasty. The close control of Thanh Hóa phủ and Phú Lương phủ must have contributed to this stability.

Nevertheless, we should pay proper attention to the frequent imperial tours. In total, 65 tours are recorded in SL and/or $\mathrm{TT}^{60}$. The first three emperors made 22 tours, Nhân Tông made 25 tours and four emperors after him (excluding the last emperor, Chiêu Hoàng, of whom no tour is recorded) made 18 tours. The three major purposes of the tour were to attend agricultural rituals (22 times), to hunt elephants (13 times) and to visit temples or shrines (10 times). ${ }^{61}$ These tours must have functioned to demonstrate imperial power and authority and to reaffirm the relationship between sovereign and subjects, as was the case of the royal tours to visit or repair pagodas undertaken by the kings of Pagan. ${ }^{62}$ Anh Tông (r. 1137-75) reportedly traveled all over the country.

Traveled [as far as] islands in the sea and inspected topography of mountains and rivers [of the whole country] because his majesty wanted to know people's pain and the distance of roads (TT-1171)

Again traveled [as far as] islands in the sea in southern and northern [peripheries] and had scenery drawn (TT-1172).

${ }^{60}$ Ibid., 244: Table 6-6. The number does not include wartime moves and processions inside the capital.

${ }^{61}$ The empress dowager Linh Nhân, mother of Nhân Tông, who shared the sovereignty with Nhân Tông (see Momoki, "Gia đình của các vua nhà Lý," 265), "traversed mountains and rivers and wanted to build temples and towers" (TT-1085). Her travel must also have been occasions to demonstrate imperial authority.

${ }^{62}$ See Michel Aung-Thwin, Pagan: The Origins of Modern Burma (Honolulu: University of Hawaii Press, 1983), 53. See also Wolters, History, Culture and Region (revised ed.), 30. 
These tours were intended to show the emperor's sovereignty all over the national territory in a symbolic way. ${ }^{63}$ In terms of economy, imperial tours may have been necessary to collect and consume local products, not all of which could be transported to the capital through the official taxation system.

For the purpose of military expedition and imperial tour, a number of outer palaces (hành cung) were built in strategic points. Some of them were not merely temporary camps. Records of agricultural ceremonies such as tích điền 籍田 (ploughing by the emperor) performed at the outer palaces of Bố Hải khẩu (in present-day Thái Bình city), Lỵ Nhân (on the bank of the Red River in Hà Nam) and Úng Phong (in the western part of Nam Đinh) indicate that rice fields under the direct imperial control were attached to the outer palaces. ${ }^{64}$ Because ceramics sherds were found together with the sherds of saggers, there must have been a kiln in Úng Phong outer palace, ${ }^{65}$ where visits by emperors were often recorded from 1101. ${ }^{66}$ In 1205, a rebel in Đại Hoàng (present-day Ninh Bình) named Phí Lang 費郎 defeated the army of the government somewhere in Nam Định, then "burned Úng Phong outer palace and its grain stored in the granary"(SL). Moreover, almost contemporaneously with the first record of Úng Phong outer palace in 1101, famous Buddhist centers of An Lão Sơn temple 安老山寺(SL-1099) and Chương Sơn tower 章山塔 (SL-1108) were built in the same vicinity. As a crucial relay point

${ }^{63}$ Cao Tông (r. 1175-1210) also "traveled mountains and rivers everywhere. Wherever the imperial palanquin went and there was a deity, he conferred a title and erected a shrine to worship [the deity]" (TT-1189).

${ }^{64}$ Sakurai, Land, Water, 192-201. Concerning the outer palaces in the lower delta region, see also Momoki Shiro, "Mấy luận điểm mới về lịch sử khai phá vùng hạ lưu châu thổ sông Hồng tring giai đọan Lý-Trần (I) Hề thống hành cung thời Lý” (Some New Arguing Points on the History of the Reclamation of the Lower Red River Delta during the Lý-Trần Period [I]: The Network of Outer Palaces in the Ly period), in Viện Việt Nam học và Khoa học Phát triển, 20 năm Việt Nam học theo dịnh hướng liên ngành (Institute for Vietnamese Studies and Development Science, 20 Years of Vietnamese Studies Following the Direction of Interdisciplinary Research) (Hà Nội; Nhà Xuất bản Thế giới, 2008).

${ }^{65}$ Dr. Nishimura Masanari (an archeologist) and I visited Bến Đền site in Minh Thuận commune (a place thought to have been the center of the outer palace) on August 7, 2002 and found on the ground some sherds of ceramics, saggers, together with sherds of Lý bricks and tiles.

${ }^{66}$ In 1151, prince Long Xưởng 竜永, the eldest son of Anh Tông, was born at Úng Phong outer palce (TT). This means Anh Tông then stayed there with his wife or his wife lived in Úng Phong. In either case, the outer palace must have had permanent architecture. 
from Thăng Long to southern centers such as Hoa Lư and Thanh Hóa, ${ }^{67}$ Úng Phong must have been fully provided with the necessary functions for a power center.

During the reign of Anh Tông, similar centers were reportedly established on or beyond the periphery of the Red River Delta, such as the mobile camp (hành dinh 行営) of Yên Hưng trại (TT-1147, in the southwestern alluvial land of present-day Quảng Ninh province), the residences (đệ 第) of Phú Lương (TT-1155) and Quảng Nguyên châu (TT-1156), and Quốc Oai outer palace (SL-1156). Yên Hưng could control routes to China by both land and water, while it may also have been an agricultural frontier, as was the case of Bố Hải khẩu. It is well known that the Lý court made great efforts to subjugate the mountainous area of Phú Lương and Quảng Nguyên in order to control the route to China, the source of gold and the minorities on the border. Benefitting from these conditions, the Nung family tried to establish their own polity in the mid-11 ${ }^{\text {th }}$ century. ${ }^{68}$ Quốc Oai may also have functioned as a junction between the delta and the hilly area. The constructions were apparently linked with the above-mentioned policies to strengthen central power and authority over the countryside, such as the intensive rule undertaken by the imperial entourage in Phú Lương and Thanh Hóa, the imperial tours over the whole country and military drafts under the lọ officials.

The outer palaces (and the headquarters of phủ as well) on and beyond the periphery of the delta were, of course, surrounded by hereditary local chiefs. Even in the lower Red River Delta, the relationship between the outer palaces and indigenous political powers in the countryside was more complicated than earlier studies supposed. For instance, the clear-cut division between

${ }^{67}$ Judged from its position, Lỵ Nhân may have been a relay point to centers on the eastern bank of the Red River such as Ngự Thiên (in the northwestern corner of present-day Thái Bình province?) and Bố Hải khẩu. In addition, it was also a relay point to Hoa Lư (on the water route) because Thái Tông returned there via Hoa Lư on his way back from Champa (TT-1044).

${ }^{68}$ On the "rebellion" of the Nung family, see James Anderson, The Rebel Den of Nung Tri Cao: Loyalty and Identity along the Sino-Vietnamese Frontier (Singapore: NUS Press, 2007). 
semi-independent territories of hereditary local powers and the areas controlled directly by the central government proposed by Sakurai Yumio is not so plausible. ${ }^{69}$ The location of Mỹ Lộc (to the north of present-day Nam Định city) as the center of the Trần family is especially problematic. It lies only about ten kilometers distant from Lỵ Nhân outer palace, which Sakurai regarded as one of Lý centers in Western Floodplain. ${ }^{70}$ Moreover, he ignored Hải Thanh outer palace recorded in SL $\left(1157 ; 1202 ; 1206^{71}\right)$, which

${ }^{69}$ Regarding other sub-regions in the Red River Delta, Sakurai thought that while the territory of local powers in the $10^{\text {th }}$ Century usually corresponded to that of later districts, that in the end of the Lý Period corresponded to the territory of later provinces. Such expansions occurred due to the development of supra-local hydraulic works (Sakurai, Land, Water, chap. 3). As mentined above, smaller military powers in units of ấp and/or huong still played considerable roles in the civil war in the end of the Lý Period.

${ }^{70}$ When a coup occurred in the court and Cao Tông and his sons fled separately, the then Trần leader Trần Lý gave protection to Prince Sam (Huệ Tông) and let him ascend the throne at Lỵ Nhân outer palace (SL-1209/7).

${ }^{71}$ According to Viên Quang tự bi minh 圓光寺碑銘 inscription erected at the end of the Lý Period (Phan Văn Các and Claudine Salmon, ed., Văn khắc Hán nôm Việt Nam tập 1: 235), Hải Thanh outer palace was located "on the left side" of Viên Quang temple. The temple is now located in Xuân Nghĩa commune, Xuân Trưởng district, although its original location is unkown. Early modern tradition of chùa Keo (Thần Quang tự 神光寺) in Thái Bình tells that the temple was originally located in Giao Thủy hương 膠水郷 (a palace name in the river mouth of the Red River on the Nam Định side) and called Nghiêm Quang temple. Regarding chùa Keo, see Nguyễn Xuân Nam, "Dấu ấn văn hóa thế kỷ XI-XII ở Nam Định góp phần với văn hóa Thăng Long - Đại Việt thời Lý tỏa sáng (Vestiges of the Culture during the $11^{\text {th }}$ $12^{\text {th }}$ Centuries in Nam Định Which Contributed to the Iluminating Culture of Thăng Long Đại Việt)," in Trường Đại học Khoa học Xã hội và Nhân văn, Kỷ yếu hội thảo khoa học: Ly Công Uẩn và vuoong triều Lý (kỷ niệm 990 năm Thăng Long-Hà Nội) (University of Social and Human Sciences, The Proceedings of the Scientific Symposium: Lý Công Uẩn and the Lý Dynasty, For the Commemration of the 990th Anniversary of Thăng Long-Hà Nội ), Hà Nội: Nhà Xuất bản Đại học Quốc gia Hà Nọi, 2001, 309. Nghiêm Quang temple in Hải Thanh 海清㛜光寺 is mentioned in Thiền uyển tập anh (25a) as the base of zen master Không Lộ 空路. Viên Quang tự bi minh inscription mentions another zen master Giác Hải 覚海, whose biography is also included in Thiền uyển tập anh. And the $15^{\text {th }}$ century collection of legends Linh-Nam chích-quái 嶺南摭怪 has an account of the magical power of these two masters. It is likely that the reclamation of Hải Thanh area was partly led by Buddhist sect(s). In every charter polity, religious sects played large enonomic and social roles. Regarding the centers of the Trần family and other related centers in Nam Định and Thái Bình, much information is introduced in local publications such as Sở Văn hóa-Thông tin Nam Hà (Nam Hà Provincial Bureau of Culture and Information), Kỷ yếu họi thảo khoa họ: Thời Trần và Hung Đạo đại vuoong Trần Quốc Tuấn trên quê hương Nam Hà (The Proceedings of the Scientific Symposium: The Trần Period and Hưng Đạo đại vương Trần Quốc Tuấn in the homeland of Nam Hà), 1996, and Sở Văn hóa Thông tin Thái Bình (Thái Bình Provincial Bureau of Culture and Information), Thái Bình với sụ nghiệp thời Trần (in lần thứ hai có chỉnh lý, biên sọan và bổ sung) (Thái Bình with the Achievements in the Trần Period, the second edition with revision and supplementation), 2001. 
Map 2. Outer palaces and other centers during the Lý Period

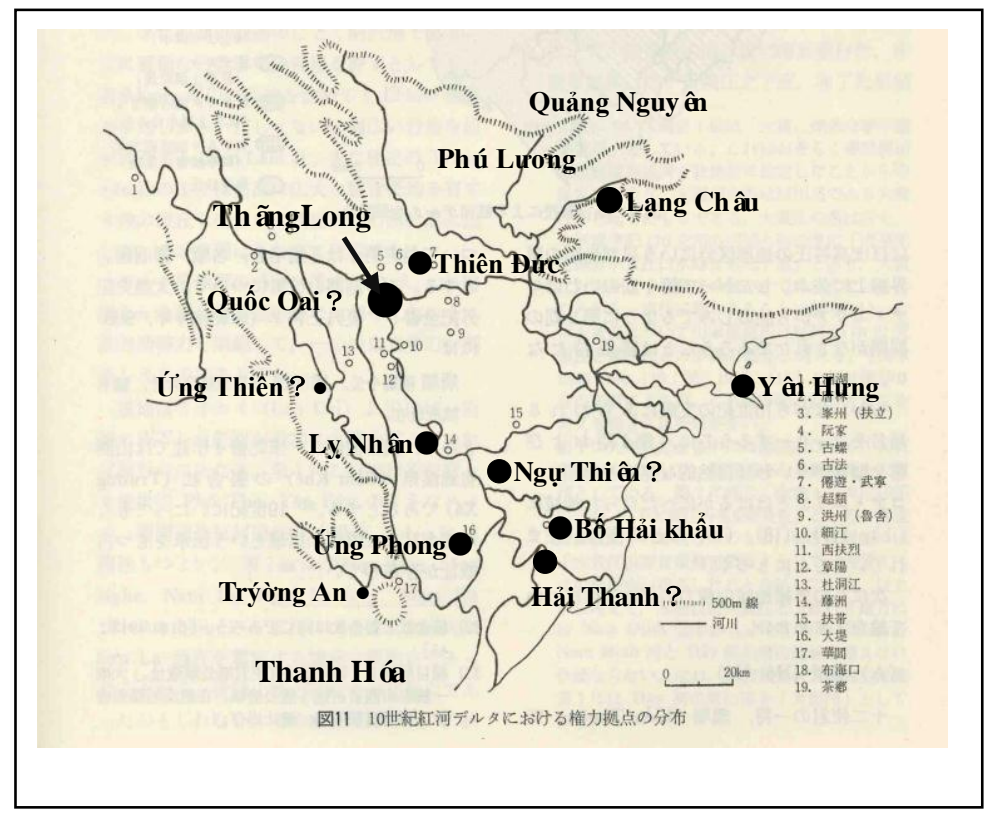

was probably located near the mouth of Red River (in present-day Xuân Trưởng district). Mỹ Lộc 美禄 (located) must have been located just between Lỵ Nhân and Hải Thanh. Across the Red River from Lỵ Nhân, there was another base of the Trần family at Đa Cương hương 多岡鄉 or Tinh Cương hương 星罡鄉 in present-day Hưng Hà district, ${ }^{72}$ where Ngự Thiên outer palace may have been located. Remember that Bố Hải khẩu outer palace in Thái Bình was established on the site of the former center of Trần Minh Công, one of "twelve lords" in the $10^{\text {th }}$ Century ${ }^{73}$. If outer palaces could be built at centers of local power, the subjugated local powers may have played some roles in the management of the palaces and surrounding facilities. If so, the Trần family would have been able to extend their power not "despite" but "thanks to" the outer palaces nearby, such as Lỵ. Nhân and Ngự Thiên, through the service related to them.

${ }_{72}$ After the coup in 1209 mentioned in note 70, Prince Sam first took refugee in Hải Âp Luu Gia thôn 海邑劉家村, which is identical with the home village of Lúu Khánh Đàm 劉慶 譚(a powerful courtier, possibly a eunuch, in the early $12^{\text {th }}$ Century) in present-day Hưng Hà district. There he was given protection by the Trần family, the Tô family on its maternal side.

${ }^{73}$ See Sakurai, Land, Water, 130-2, 200-1. 


\section{Local Rule by Princesses?}

As mentioned above, the Lý family had close ties with the Thân family in Lạng Châu through marriage between Lý princesses and Thân male chiefs. ${ }^{74}$ The ties were so strong that Huệ Tông tried to take refugee in Lạng Châu when he and his mother (Đàm Thái hậu 譚太后) were pressed to leave the capital by Trần Tự Khánh in the first lunar month of 1214 (SL). Further evidence of the close relationship is the rebellion of Thân Lợi in 1139, in which the present-day Northeast (Đông Bắc) region as a whole seems to have been involved. After the death of Thần Tông in 1137, Thân Lợi claimed to be a son of Nhân Tông and rebelled. He occupied Phú Lương phủ and intended to attack the capital, but he was defeated by Đỗ Anh Vũ at Quảng Dịch and Long Lệnh châu and fled to Lạng Châu, where he was arrested (SL-1139, TT-1141). It is quite likely that he belonged to the Thân family in Lạng Châu and claimed the throne based on his maternal line. ${ }^{75}$ In such marriage alliances, the princesses were not simply the puppets of male-centric policies. ${ }^{76}$

Thiên Thành công chúa 天成公主, a daughter of Thánh Tông who married Thân Đạo Nguyên 申道元 ${ }^{77}$ (SL-1066), presented to Nhân Tông a “tortoise with three legs and six eyes 三足六眸 龜”(SL-1079) and two white elephants (SL-1106). ${ }^{78}$ These records

${ }^{74}$ This relationship is analyzed closely with recent information regarding archeological sites and local worship related to these persons in in Sở Văn hóa, Thể thao và Du lịch tỉnh Bắc Giang, Ủy ban Nhân dân huyện Lục Ngạn (Bắc Giang Provincial Bureau of Culture, Sports and Tourism, People's Committee of Lục Ngạn district), Hội thảo Khoa hoc: Bảo tồn và Phát huy các giá trị di sản văn hóa Lý - Trần, tỉnh Bắc Giang (Scientific Symposium: Preservation and Exhibition of Cultural Values in the Lý - Trần Period in Bắc Giang province), 2010.

${ }^{75}$ See Momoki, Chusei Daietsu, 208.

${ }^{76}$ I presented a brief argument about the role of princesses in local rule in my previous works. See Momoki, "Gia đình của các vua nhà Lý," 262, and Chusei Daietsu, 220-1.

77 Đạo Nguyên's mother was Bình Dương công chúa 平陽公主 (SL-1066) who married Lạng Châu mục Thân Thiều Thái 申紹泰(SL/TT-1029). Thiều Thái’s father Thừa Quý 承貴 was also recorded in 1027 in Chinese sources as a "son-in-law of Lý Công Uẩn." See Momoki, "Vetonamu Richo no gunji kodo," 406.

${ }^{78}$ Thiền uyển tập anh tells that when Zen master Chân Không (see note 44 above) passed away in 1100, the Empress Dowager, Thiên Thành công chúa (天城公主), and the nun Mậu Nhân, who was a disciple of Chân Không, all offered things for his memorial (66a). Probably this Thiên Thành is identical with Thiên Thành who married in 1066 and reportedly died in 1149 (TT). 
imply a princess who married into a local family maintained her own property right. ${ }^{79}$ This assumption is probably substantiated by the records below:

[Ordered to] construct the residence (đẹ 第) of Thụy

Thiên công chúa 瑞天公主 at Lạng Châu (TT-1147).

Thụy Thiên công chúa arrived at Lạng Châu (TT-1148).

Đinh Khôi attacked Lạng Châu and caused it to surrender, then plundered the residence of Thiên Cực công chúa 天極公主 and went away (SL-1212/1).

Recent excavations at Cầu Tử Shrine site in Lục Ngạn district revealed a large architectural remnant of the $12^{\text {th }}$ to $13^{\text {th }}$ Century associated with various high-quality artifacts similar to those found in Thăng Long and other major sites in the Lý Dynasty, including ceramics, bricks and rooftiles, and especially square tiles with decorations of lime flowers. ${ }^{80}$ According to local tradition, Bình Dương công chúa and Thân Thiều Thái had two "palaces" in present-day Tòng Lệnh commune (where another large archeological site called chùa Cao was found) in Lục Nam district and Phương Sơn commune in Lục Ngạn district. ${ }^{81}$ The residences of Thụy Thiên and Thiên Cực may have been as magnificent as the architecture found in Cầu Tử and the "palaces", which were all constructed in the center of Lạng Châu on the Lục Nam River.

It is not clear whether Thụy Thiên công chúa was married to a local chief or not. It is not impossible that she lived alone in the estate of Lạng Châu. Nor is it clear whether the above Thiên Cực công chúa is identical with the princess of the same title who

${ }^{79}$ TT-1013 states, "allowed nobles and princesses to supervise various taxes in different ranks." Princesses in general were guranteed their own rights of property and profit, though through what mechanism princesses received the profit is unkown.

${ }^{80}$ See Trịnh Hoàng Hiệp, "Di tích đèn Cầu Tử (The Cầu Từ Shrine site)," in Sở Văn hóa, Thể thao và Du lịch tỉnh Bắc Giang, Ủy ban Nhân dân huyện Lục Ngạn, Hội thảo Khoa học 2010: 8-9. Cầu Từ shrine worships Bình Dương công chúa.

${ }^{81}$ Ibid., 13-14. 
married Lạng Châu mục Hoài Trung hầu 懐忠侯 in 1167 (SL). Tô Trung Tự 蘇忠嗣, the maternal uncle of the Trần leader Tự Khánh, commited adultery with Thiên Cực công chúa at her residence in Gia Lâm (on the opposite side of the Red River with Thăng Long) and was killed by her husband Quan nội hầu Vương Thượng 關 内侯王尚 (SL-1211/6). Thiên Cực công chúa recorded in 1211 and 1212 (who was young enough to commit adultery) may have been a different person from the Thiên Cực who married in 1167. In either case, it is obvious that a married princess could possess properties including residences and estates. ${ }^{82}$

The presents given by Thiên Thành công chúa may be understood as auspicious items given as tribute symbolizing peaceful rule in Lạng Châu. Such tribute is usually the duty of the governor of the locality. In the case of Thiên Thành công chúa, she may have assumed such a role after the death of her spouse as the widow of a patriarch. However, the property rights and political powers were not confined to those within a patriarchal framework. According to TT-1222, as quoted above, the whole country was divided into 24 lọ units and Circuit Princesses (?) settled there. Bond servants and slaves, and soldiers in the circuit as well, were divided into giáp troops. Then TT-1224 explains why Trần Thủ Độ, who would "produce" the transfer of the throne to the Trần family in the following year, could seize absolute power in the court of Huệ Tông:

The Emperor's illness became worse day by day, [However, his majesty] did not have an heir to succeed to the throne, and princesses were stationed at circuits to make the circuits their domains. [Therefore his majesty had to] charge Commander-in-chief Trần Thủ Độ with troops of the palace guard to guard the forbidden area.

According to this logic, Trần Thủ Độ would not have been able to seize power if princesses had stayed at the central court. With such political power and influence, princesses who went out to local areas may have taken part in the local rule in a broader 
sense.

\section{OVERVIEW AND COMPARISON}

Among varuous local units during the Lý Period, two ranks can be discerned. Units of the higher rank were usually called châu, while those of lower rank were called hurong in lowland and sách or đọng in mountainous areas. It is unlikely that the state's power penetrated into natural villages below the rank of huong. These units appear to have been regarded as customary ones in a general sense rather than functional units set up administratively by the dynastic government. Following individual historical and political conditions, some of these units could have had different denominations from popular ones like châu and hưong. It is doubtful whether the central court could replace such customary units with more strictly controlled administrative units (such as huyện and xã in later periods) even in the core region of the Red River Delta. The central court could only intervene in those units by promoting (or downgrading) the rank or status of those units, for example from a hương to a châu or from a châu to a phủ, based on the strategic importance or the merit and honor of the units concerned. Some functional units, including $l \hat{o}$ as military jurisdictions, were set up administratively from above. When such a jurisdiction overlapped with a customary one, however, it was seldom recorded as a substantial entity.

The customary units were generally governed by hereditary indigenous chiefs such as thủ lĩnh and châu mục in châu units. Sometimes imperial family members or high-ranking courtiers were dispatched to govern those units. While local chiefs could be mobilized to participate in the affairs of regions other than their own, the governors dispatched from the center do not appear to have always enforced a more centralized administration than that undertaken by indigenous chiefs. In two phủ units of Phú Lương and Thanh Hóa, however, more "nameless" imperial attendants 
or secretaries (of private character) were appointed as governors in the first half of the $12^{\text {th }}$ Century. This implies that more intensive rule was introduced into these ruling centers outside the Red River Delta.

Non-institutional channels of rule also played important roles in enhancing the influence of the central court in local society. The emperors and princes in the first three reigns had personally to lead expeditions to subjugate local powers in and beyond the peripheral areas of the Red River Delta. From the reign of the fourth emperor Nhân Tông, imperial tours made on the pretext of religious and ritualistic purposes played similar roles to the military expeditions as demonstrations of imperial power and charisma. A number of outer palaces with not only military but also economic and religious facilities were set up at strategic points and could function as centers of local rule. Princesses, especially those who married into families of local chiefs, also participated in the politics of the local communities, having their own property and political influence that were not incorporated into the framework of patriarchal family system.

Through this combination of means, the Lý government extended its control over local communities, even outside the Red River Delta, by the early $12^{\text {th }}$ Century. This was a significant gain for a solar polity. Nevertheless, as mentioned in note 19, the military draft in 1160 (TT) caused large-scale unrest:

Ordered Phi Công Tín, leading one hundred thousand soldiers, to pacify deserters from the army who plundered inhabitants (TT-1163).

The confused battles that took place at the end of the Lý Period indicate that indigenous military powers had remained intact even in the Red River Delta. In the hilly areas surrounding the delta, conflicts with "mountainous barbarians (sơn lao 山獠)" escalated from the $1150{ }^{83}$ From the reign of Anh Tông (1137-75), the extension of central power to local communities appears to have exceeded the capacity of a solar polity and ultimately caused

3 The activities of Son lao recorded mainly in the western edges of the delta $(1152 ; 1184$; 1185) may have been influenced by the general expansion of Tai people in northern mainland Southeast Asia. See Momoki, Chusei Daietsu, 240. 
the collapse of the Lý ruling system as a whole. ${ }^{84}$

Finally, let us examine the local administrative system of Goryeo (before the Warirer Regime that was established in the end of the $12^{\text {th }}$ Century) in comparison with that of Đại Việt in order to understand the wider regional background against which Đại Việt localized Chinese models (mainly those of the Tang and the Song).

In the case of Goryeo, high-ranking local administrative units were originally powerful and/or honoured settlements or families which had inherited the title of gun 郡(quận) or hyeon 県 (huyện) from the Silla Period (-935). They dominated weaker settlements of various categories including ordinary "villages" (chon 村) and settlements that were discriminated like bugok 部 曲, hyang 鄉, jin 津 and so 所. Especially powerful settlements or families could be conferred the title of bu 府 (Vietnamese < phủ). They not only dominated their own subordinate units like chon and bugok, but also controlled surrounding high-ranking units likeju 州 (châu), gun 郡 (quận) and hyeon 県 (huyện), which in turn, dominated similar subordinate units. The royal court also set up its own subordinate units such as jang 荘 and cheo 処 as economic bases. In the beginning of Goryeo, most gun and hyeon units did not have officials appointed by the central government. In other words, the chief of such a unit was not given a title by the central government though the locality itself was given a title as an administrative unit. Instead, such sokgun 属郡 and sokhyeon 属県 units were controlled by a nearby gun or hyeon which had officials appointed by the central government. And the central power never penetrated into lower-rank units, where local chiefs governed as non-career officials (hyangri 郷吏) throughout the Goryeo Period. Units of lower-rank such as bugok, hyang, so and jang were often promoted to $j u$, and gun, and hyeon were often

\footnotetext{
${ }^{84}$ Of course, this does not exclude the argument of Sakurai regarding the advance of large-scale agricultural development in the delta, and the possibility of colder climate after the long Middle Ages Anomaly as well, as the background of the Lý collapse.
} 
promoted to ju or bu. It is quite likely that most local unit names in Đại Việt originally indicated settlements or local chiefs, with some units directly controlled by the central government such as trại (of military functions in the periphery) and truoòng (of economic functions). ${ }^{85}$ Promotions and degradation of unit titles, and the incompetency of the state power below the high-rank local units as well, were also ordinary matters in Đại Việt during the Lý Period that the central government.

From the reign of Seongjong 成宗 (982-97), the central court tried to impose governors of $j u$ and hyeon (outer offici $\rightarrow$ als or oeguan 外官) who were selected from the central bureaucratic apparatus upon gun and hyeon areas. Though many sokgun and sokhyeon remained, mainly in southern regions, the oeguan system was almost complete by $1018,{ }^{86}$ following Chinese models from the late-Tang to the Song Periods. The title of ju (or gun 軍) varied based on the importance of respective units and the status of the appointees, such as jeoldosa 節度使, bangeosa 防禦使, anmusa 安掹使 and jiju 知州 (after 1018). In this system, the title of hyeonryeong 県令 was that of lesser ju units. Above such a system centered on $j u$ and hyeon, centers such as four "capitals (kyeong 京),” “protectorates general (dohobu 都護府)” and muk 牧 units were set up to control governors of surrounding high-

${ }^{85}$ See Hatada Takashi, Chosen chusei shakaishi no kenkyu (A Study of the Social History of Medieval Korea), Tokyo: Hosei University Press, 1972. People who lived in such units as bugok, hyang and so were regarded by Hatada as people of discriminated status. Recent studies, however, treat them as comonners. See Chosenshi Kenkyukai, ed., Chosenshi Kenkyu Nyumon (A Research Guide to Korean History) (Nagoya: Nagoya University Press, 2011), 118. Between ordinary commoners (baekjeong 白丁) and slaves (nobi 奴婢), there must have been various groups who had special legal status and specified forms to serve or pay tribute to the state. Such a situation is also found in Đại Việt (see Katakura Minoru, Betonamu zenkindai-ho no kisoteki kenkyu [A Preliminary Study of the Pre-Modern Legal System in Vietnam] [Tokyo: Kazama Shobo, 1987]), though the denomination of such groups as settlements (possibly including giáp and $x \tilde{a}$ ) is still to be studied. The tripartite status system of Pagan in Burma with asan or adhi (who were subject to ordinary tax), kywan-to or ahmu-dan (who were subject to specified labor or tribute) and bondsmen/slave should also be remembered. Concerning Pagan, see Aung-Thwin, Pagan, 79-91; Lieberman, Strange Parallels, vol.1, 113.

${ }^{86}$ Four doho, eight muc, fifty-six jijugunsa 知州郡事, twenty-eight jinjan 鎮将 and twenty hyeonryeong 県令 were appointed in this year. See Sudo, 1980, “Korai shoki no Chiho Seido (Local Administration in Early Goryeo)," in Korai-cho kanryo-sei no kenkyu (A Study of the Bureaucracy of the Goryeo Dynasty), ed. Sudo Yoshiyuki, (Tokyo: Hosei University Press, 1980), 192-200. 
er-ranking units. Here, Tang (dohobu) and ancient Chinese (muk) denominations were employed, and those units were still regarded as ju of special status, as was the case of $\mathrm{fu}$ in Tang China. ${ }^{87}$

In the larger jurisdictions of do 道, which numbered ten in 995 but were reorganized into five do and two gye 界 in 1186, wide-area superintendents (gamsa 監司) were appointed to inspect military, financial, judicial, administrative and other affairs. Song-modeled titles like jeonunsa 転運使 (-1029) and ancholsa 按察使 were employed for the superintendents. In the peripheral jurisdictions in the Northwest, Northeast and Southeast, special military commanders were appointed as byeongmasa 兵馬使 or dobuseosa 都部署使. ${ }^{88}$ Their jurisdictions were sometimes called no 路 (Chinese <lu; Vietnamese $<l o \hat{0}) .{ }^{89}$ Though the diversity of denomination of high-ranking units and their governors (and probably the system in which local units were basically divided into two levels) was common to both countries, such a centralized and bureaucratic system of local rule was absent in Đại Việt in this period.

Regarding non-institutional channels, Goryeo was quite different from Đại Việt. Though both polities were established based on the federation of local powers, princesses of the Goryeo royal family did not marry into powerful local families. ${ }^{90}$ Goryeo

${ }^{87}$ Ibid., 176-231.

${ }^{88}$ Ibid., 231-55.

${ }^{89}$ The central court appointed military commanders (usually byeongmasa 兵馬使) of Northern and Eastern territories (Bukgye 北界 and.Donggye 東界) permanently in the $11^{\text {th }}$ Century. The territories were indicated both as Northwestern Region (Seobuk myeon 西北面) and Northeastern Region (Dongbuk myeon 東北面), and Northwestern Circuit (Seobuk no 西 北路) and Northeastern Circuit (Dongbuk no 東北路). Probably because these two peripheral areas were under military superintendency, the areas themselves may also have been referred to as circuits, as shown in the record "two provinces of Mun and Yong in Northeastern circuit 東北路文勇二州” (Goryeosa or the official history of Goryeo, the $7^{\text {th }}$ year of the king Munjong (1053).

${ }^{90}$ Instead, the royal family in the mid-Goryeo Period enforced endogamy as did the Trần in Đại Việt. This means that the political and administrative centralization in both charter polities was not always accompanied by Confucianization. Probably it was more important for Goryeo to exclude the power of the maternal side than for the Lý. As for marriage alliances 
kings often went in procession to Seo Gyeong 西京 (present-day PyeongYang), the second capital, from where the first king, Wang Geon, emerged. But they seldom traveled to other places outside the main capital Gae Song.

In sum, local rule in Goryeo and Đại Việt shared many initial conditions based on the nature of actual local-power units and Tang-modeled theory of hierarchy and denominations, with which both charter polities had to pursue the common goals of small empires in the Sinic World, namely, uniform and centralized rule over the whole country ${ }^{11}$ and patrilineal succession to the throne. However, different systems developed in these polities due to not only domestic but also inter-state conditions. Among the latter conditions, confrontation with Kitan and Jurchen may have made Goryeo more eager to introduce Song models in terms of centralized ju and hyeon administration in the core region and the system of military superintendence in the northern (and southeastern) peripheries as well. For Đậi Việt, it may have been more important to maintain Tang (and pre-Tang) systems in order to claim the position of the Southern Empire with equal status to the real Chinese Empire that was the Song.

with local chiefs (of other ethnic groups), the Lý seems to have been more loyal to the Tang model.

91 On the similarity of both polities in the economic sphere such as land-holding and tax systems, see Momoki, Chusei Daietsu, chap. 1. 
Table: Local units recorded in SL and TT [Momoki, Chusei Daietsu, 232-3]

\begin{tabular}{|c|c|}
\hline Unit & (source and year) \\
\hline $\begin{array}{l}\text { 京 } \\
\text { Kinh }\end{array}$ & $\begin{array}{l}\text { 昇竜 Thăng Long 京（TT-1010;1014; 1024; 1028），南京 Nam Kinh } \\
\text { (SL,TT-1014) }\end{array}$ \\
\hline $\begin{array}{l}\text { 城 } \\
\text { Thành }\end{array}$ & $\begin{array}{l}\text { 華閭 Hoa Lu 城（SL,TT-1010），大羅 Đại La 城（SL,TT-1010; TT-1028; } \\
\text { SL,TT-1078; SL-1165），昇竜 Thăng Long 城（TT-1010），長安 Trường An } \\
\text { 城（TT-1028） }\end{array}$ \\
\hline $\begin{array}{l}\text { 行宮 } \\
\text { Hành } \\
\text { cung } \\
\text { (行 営 } \\
\text { Hành } \\
\text { dinh, } \\
\text { 第 Đệ) }\end{array}$ & 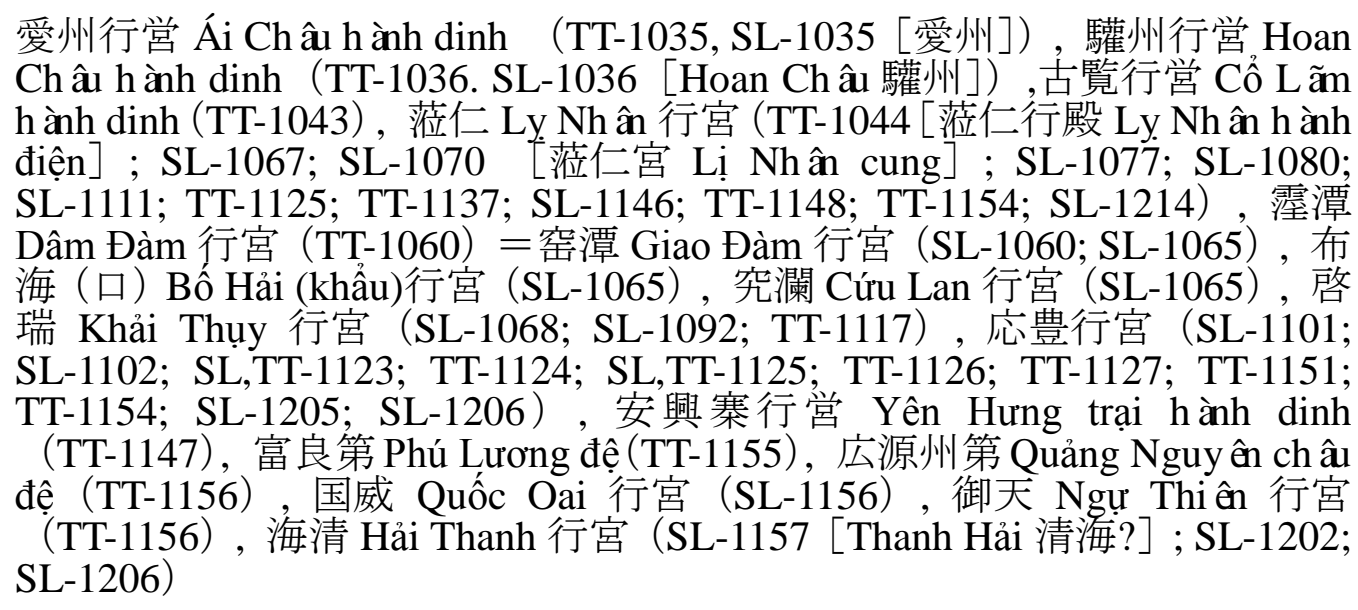 \\
\hline 路 Lộ & $\begin{array}{l}\text { 烏路 Ô lộ (SL-1030; SL-1037) =鳥路 Điểu lộ (TT-1030; TT-1037)，又安 } \\
\text { Nghệ An 路(TT-1154*)，烘路 Hồng lộ (SL-1209), 快路 Khoái lộ (SL-1215), } \\
\text { 上源 Thượng Nguyên 路 (SL-1220) }\end{array}$ \\
\hline 府 Phủ & $\begin{array}{l}\text { 京府 Kính phủ (TT-1010), 天徳 Thiên Đức 府 (SL,TT-1010; SL in the be- } \\
\text { ginning of the reign of Thái Tô; Thái Tông, Thánh Tông and Nhân Tông; } \\
\text { TT-1128; SL in the beginning of the account Thần Tông; Anh Tông and Cao } \\
\text { Tông), 長安 Trưởng An 府 (SL,TT-1010; TT-1013; SL,TT-1028; SL,TT in the } \\
\text { beginning of the account of Thái Tố; SL,TT-1044; TT-1141*; TT-1154*), 応天 } \\
\text { Úng Thiên 府 (SL, TT-1014) , 都護 Đô Hộ 府 (TT-1037; TT-1067; } \\
\text { SL,TT-1072; SL-1097; SL-1107; TT-1126; TT-1130; SL-1198; SL-1210; } \\
\text { SL-1218), X安 Nghê An 府 (SL-1101), Thanh Hóa 清化府 (SL,TT-1111; } \\
\text { TT-1127; TT-1128; TT-1129; TT-1130; TT-1132; TT-1135; TT-1136; TT-1137; } \\
\text { TT-1152; SL-1192; SL-1198; SL,TT-1199; SL,TT-1203; SL-1210)、富良 Phú } \\
\text { Lương 府 ( TT-1125; TT-1127; SL-1139= TT-1141; TT-1142; TT-1147; } \\
\text { TT-1149)、星罡 Tinh Cương 府 (SL-1225)，安華 An Hoa 府 (SL in the end } \\
\text { of the account of Huệ Tông) }\end{array}$ \\
\hline 州 & $\begin{array}{l}\text { 古法 Cổ Pháp 州（T-1009、TT in the beginning of the reign of Thái Tổ; } \\
\text { TT-1010; TT-1034; T-1161 ) , 驩 州 Hoan Châu ( TT-1010; TT-1014; } \\
\text { SL,TT-1025; SL,TT-1029; SL,TT-1031; TT-1034; SL,TT-1036; SL-1101) =X } \\
\text { 安 Nghê An 州 (TT-1036; TT-1037; TT-1041; TT-1044; SL-1069; TT-1125; } \\
\text { SL,TT-1128; TT1128; SL,TT-1132; TT-1134; SL-1136; TT-1137; SL-1148; } \\
\text { TT-1152; SL,TT-1177; SL,TT-1203; SL-1208; TT-1216; SL-1218; SL-1225), } \\
\text { 愛州 Ái Châu (TT-1010; SL,TT-1011; TT-1028*; SL,TT-1029; SL,TT-1035; } \\
\text { SL,TT-1043; SL-1050; SL-1061), 演州 Diê̂n Châu (SL,TT-1012; SL,TT-1026; } \\
\text { TT-1103; SL-1192; TT-1198)，渭龍 Vị Long 州 (TT-1012; SL,TT-1013; }\end{array}$ \\
\hline
\end{tabular}




\begin{tabular}{|c|c|}
\hline & 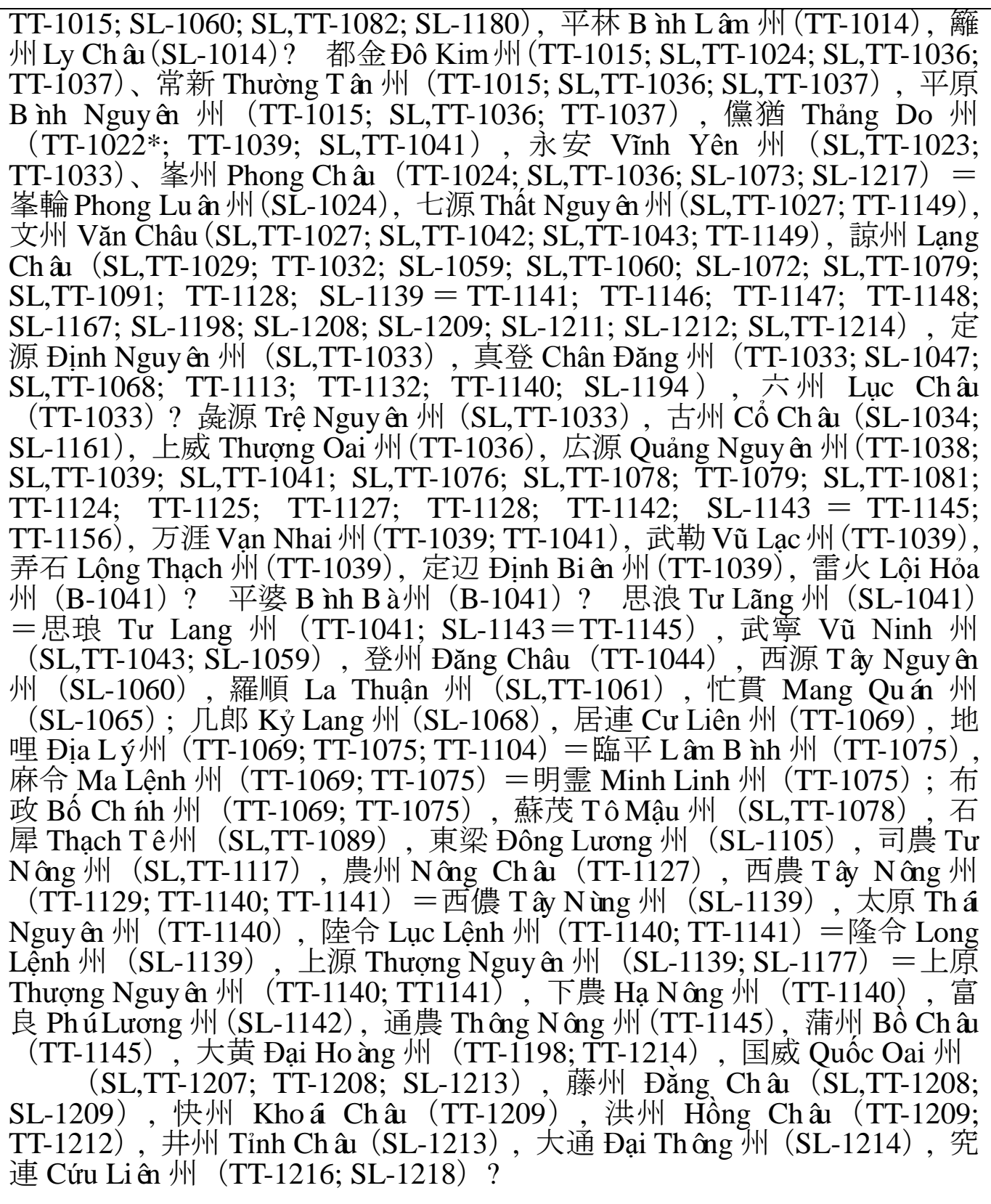 \\
\hline 道 Đạo & 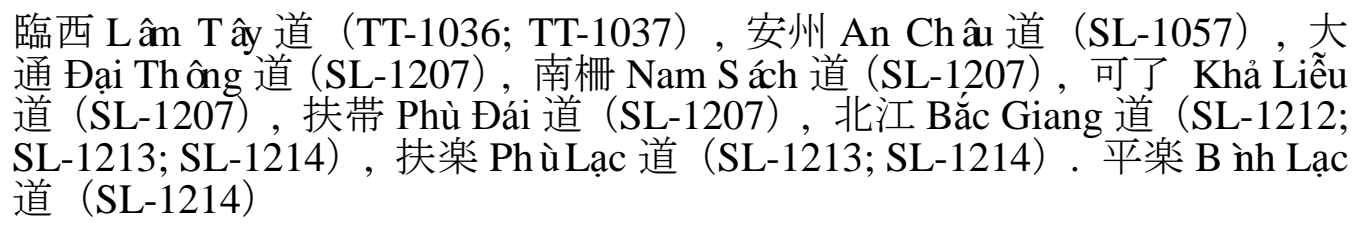 \\
\hline & 嘉林 Gia Lâm 郡（SL,TT-1062） \\
\hline $\begin{array}{l}\text { 県 } \\
\text { Huyện }\end{array}$ & 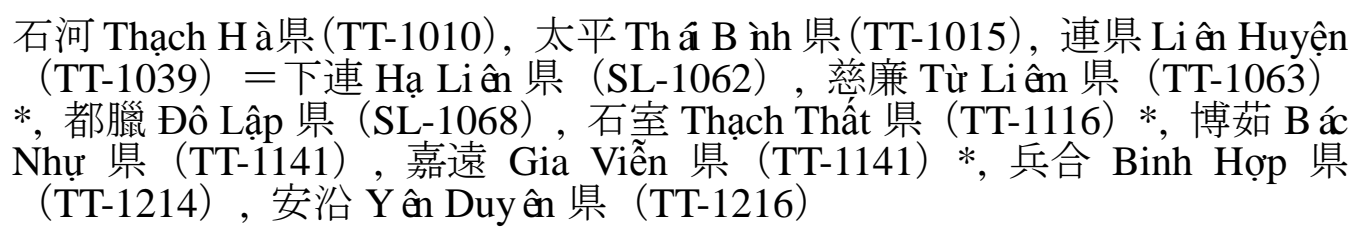 \\
\hline 鎮 Trấn & $\begin{array}{l}\text { 潮陽 Triều Dương 鎮（SL,TT-1023），永康 Vĩnh Khang 鎮（TT-1044），望 } \\
\text { 国 Vọng Quốc 鎮 (SL,TT-1047)，大通 Đai Thông 鎮 }(\text { TT-1148），帰仁 Qui } \\
\text { Nhân 鎮（TT-1148），雲屯 Vân Đồn 鎮 (TT-1184) }\end{array}$ \\
\hline & $10)$ \\
\hline
\end{tabular}




\begin{tabular}{|c|c|}
\hline 寨 Trại & 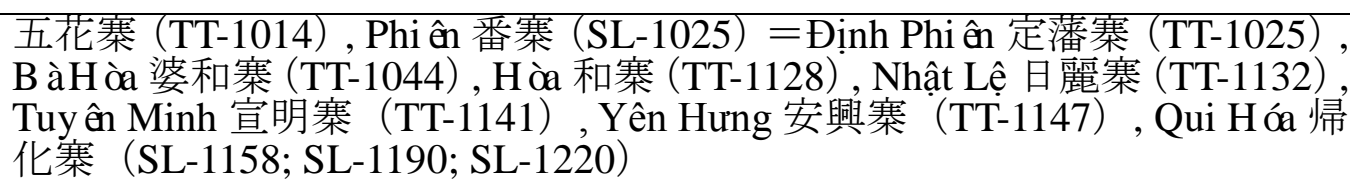 \\
\hline $\begin{array}{l}\text { 洞 } \\
\text { Động }\end{array}$ & 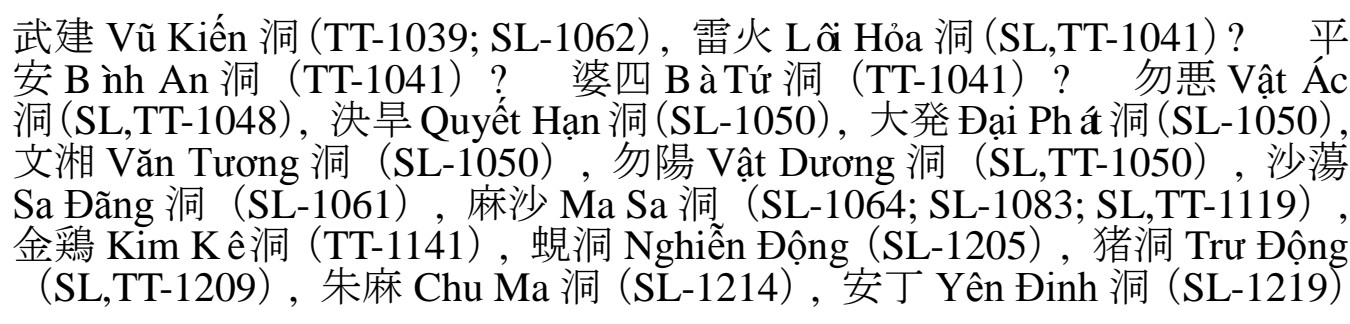 \\
\hline 柵 ( 冊) & 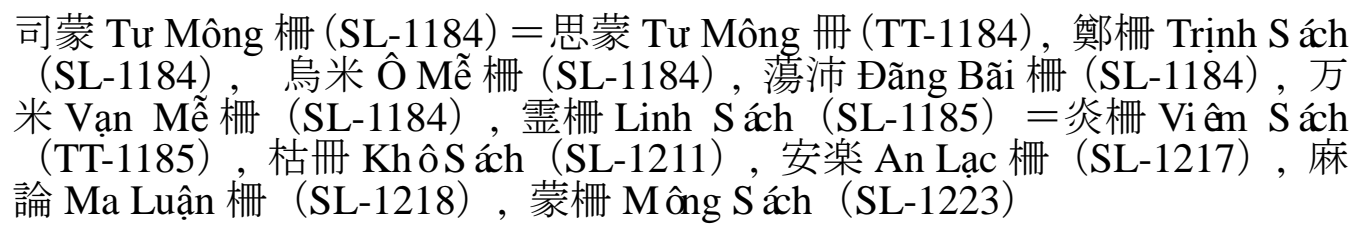 \\
\hline 郷 & 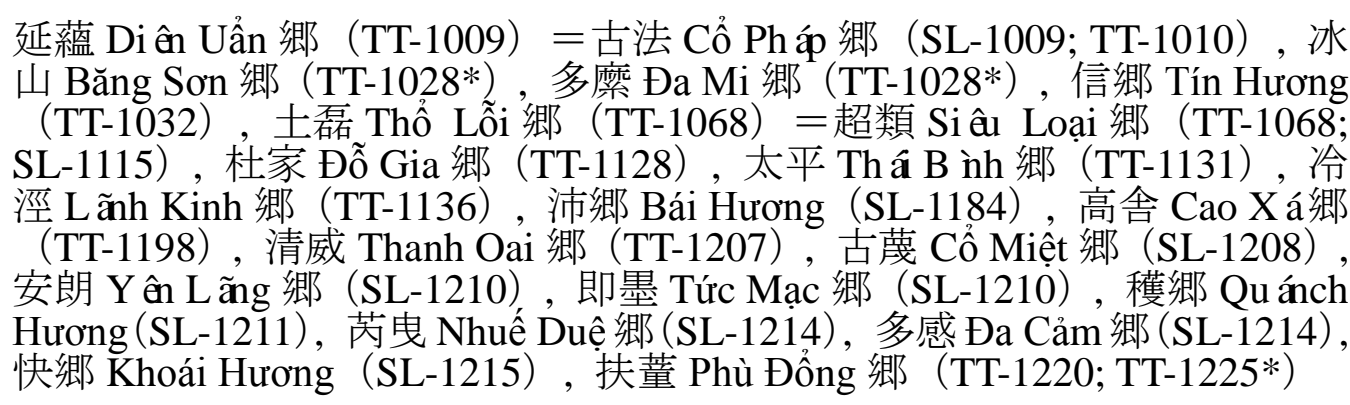 \\
\hline $\begin{array}{l}\text { 甲 } \\
\text { Giáp }\end{array}$ & $\begin{array}{l}\text { 但乃 Đãn Nãi 甲 (SL,TT-1029), 竜池 Long Trì 甲 (SL-1050), 甘蔗 Cam Giá } \\
\text { 甲 (TT-1117), 直邪 Trực Tà 甲 (TT-1117)？ 漆作 Tất Tác 甲 (TT-1120), } \\
\text { 古宏 Cổ Hoàng 甲 (SL-1188; SL,TT-1192) }\end{array}$ \\
\hline $\begin{array}{l}\text { 場 } \\
\text { Trường }\end{array}$ & $\begin{array}{l}\text { 快場 Khoái Trường（TT-1119），桄榔 Quang Lang 場（TT-1128），平隆 Bình } \\
\text { Long 場（SL-1161） }\end{array}$ \\
\hline 邑 Ấp & 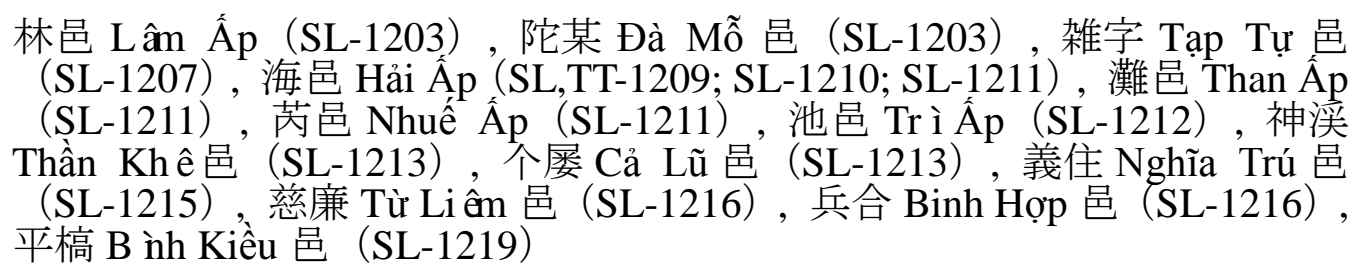 \\
\hline $\begin{array}{l}\text { 江 } \\
\text { Giang }\end{array}$ & 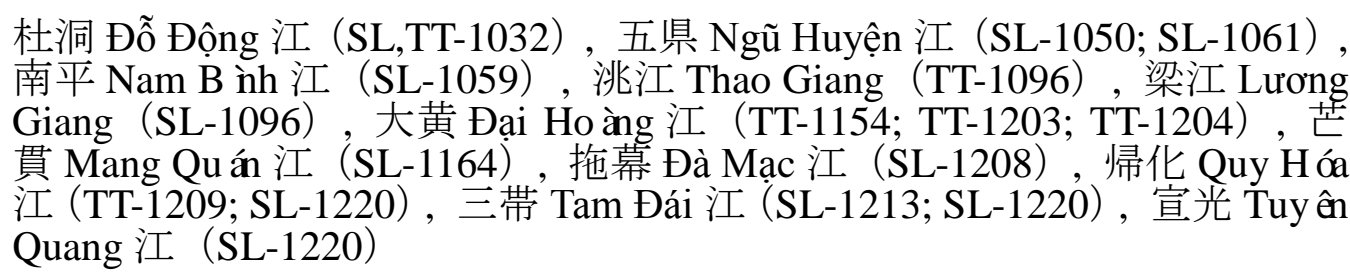 \\
\hline 社 X̃̃ & $\begin{array}{l}\text { 駅望 Dịch Vọng 社（TT-1063*)，譚舎 Đàm Xá 社（TT-1141*），麻浪阿杲 } \\
\text { Ma Lãng A Cảo (Làng Cảo?)社（SL-1209） }\end{array}$ \\
\hline
\end{tabular}


84 | ASIAN REVIEW OF WORLD HISTORIES 1:1 (JANUARY 2013)

村 古碑 Cổ Bi 村 (TT-1028*), 譚舎 Đàm Xá 村 (TT-1028*)，杜家 Đỗ Gia Thôn 村 (SL-1185), 劉家 Lưu Gia 村 (SL,TT-1209), 象奴 Tượng Nô 村 (SL-1214)

+Year with an asterisk shows the place name appears in a comment of TT's compilers. 